\title{
Strontium and stable isotope evidence for diet and mobility in Roman Gloucester, UK
}

Carolyn Chenery ${ }^{1,2}$, Gundula Müldner ${ }^{1}$, Jane Evans ${ }^{2}$, Hella Eckardt ${ }^{1}$ Mary Lewis $^{1}$

${ }^{1}$ Department of Archaeology, School of Human and Environmental Sciences, University of Reading, Reading, Berkshire RG6 6AB, UK.

${ }^{2}$ NERC Isotope Geoscience Laboratory, British Geological Survey, Keyworth, Nottingham.

This work should be cited as:

Chenery, C., G. Muldner, et al. (2010). "Strontium and stable isotope evidence for diet and mobility in Roman Gloucester, UK." Journal of Archaeological Science 37(1): 150-163.

\begin{abstract}
This paper presents the results of an isotopic investigation of population and dietary diversity in Roman Gloucester, focusing on individuals found in a late 2nd century AD mass burial pit at London Road, and comparing them to those found in the nearby cemetery. There were no statistical differences in isotopic composition between mass grave and cemetery burials, suggesting, in agreement with the osteological evidence, that the mass burial was the result of a catastrophic event, probably an epidemic disease. Strontium and oxygen isotope analysis demonstrated considerable diversity in the origins of the Gloucester population, with evidence for both UK and non-UK individuals. Diet was predominately terrestrial and similar to that of other Romano-British populations. Elevated $\delta^{13} \mathrm{C}_{\text {dentine }}$ ratios in some individuals are correlated with raised $\delta^{18} \mathrm{O}_{\mathrm{p}}$ values and are therefore probably due to childhoods spent in warmer climates, rather than dietary variation.

Given the geological complexity of the Gloucester area, this study also provides new biosphere ${ }^{87} \mathrm{Sr} /{ }^{86} \mathrm{Sr}$ data for the wider region. A technical appendix gives details on the analytical methods employed by the NERC Isotope Geoscience Laboratory (NIGL) in the measurement of oxygen stable isotope ratios of biogenic phosphate $\left(\delta^{18} \mathrm{O}_{\mathrm{p}}\right)$ and evaluates different phosphate oxygen-meteoric water conversion equations using data from Britain.
\end{abstract}

Keywords: isotopes, strontium, oxygen, carbon, nitrogen, bone, Roman, method

\section{Introduction}

Britain under Rome was a multi-cultural society, with historical and epigraphic evidence recording the voluntary and forced migration of Gaulish, Germanic and North African individuals into the British provinces (Birley, 1979). This paper presents the results of an isotopic investigation of population and dietary diversity in Roman Gloucester, focusing on individuals found in a late 2nd century mass burial pit at London Road, and comparing them to those found in nearby discrete burials.

Mass burials are rare in the archaeological record, but offer potential for the investigation of specific events and cultural behavior within a narrow time frame. Mass burials are often explained in terms of casualties of war and small scale conflicts, or ethnic 
cleansing (Fiorato et al., 2007; Wahl and König, 1987); epidemics (Grainger et al., 2008; Shoesmith and Stone, 1995); or for the disposal of the community's poor. For example, outside the City of Rome, 'puticuli' - or grave pits containing the bodies of slaves and paupers, are attested (Toynbee, 1971: 49).

The $2^{\text {nd }}$ century mass burial from Roman Gloucester (Glevum) offers the opportunity to test, whether it was the result of a catastrophic event, possibly a disease, affecting all members of the community. Alternatively, if the individuals within the pit were different to the 'regular' inhabitants of Gloucester, in their geographic origin or diet, other explanations for their mode of burial would have to be sought. More generally and as part of a larger project exploring diversity in Roman Britain, this study also allows us to explore diet and mobility at one of Britain's four colonia towns.

Various recent studies have combined strontium $\left({ }^{87} \mathrm{Sr} /{ }^{86} \mathrm{Sr}\right)$ and phosphate oxygen isotope $\left(\delta^{18} \mathrm{O}_{\mathrm{p}}\right)$ analysis of tooth enamel to characterize the local and non-local components of cemetery populations (e.g. Müller et al., 2003; Budd et al., 2004; Evans et al., 2006a, 2006b). However, these methods depend upon our ability to characterize 'local' isotope values which is not always straightforward (see Bentley et al., 2004). . In order to achieve this and given the complex geology of the Gloucester area, we have conducted a survey of biosphere ${ }^{87} \mathrm{Sr} /{ }^{86} \mathrm{Sr}$ values within a $30 \mathrm{~km}$ radius around the city, using modern vegetation samples.

\section{Roman Gloucester (Glevum)}

The city of Gloucester is located in SW England on the east bank of the river Severn, near the Welsh border (Fig. 1). Roman activity began around AD 49, with the construction of a fortress at Kingsholm (Hurst, 1985), located next to a thriving pre-Roman settlement (Hurst, 1999). In the mid to late $60 \mathrm{~s} \mathrm{AD}$, a new legionary fortress was built $0.5 \mathrm{~km}$ to the south, which eventually became a colonia, a settlement designed for retired legionaries and their families, at the end of the 1st century AD (Hassall and Hurst, 1999; Hurst, 1999, 2005; Wacher, 1974). At the close of the 1st century AD, the origin of the veteran population would still have been, for the most part, from outside Britain (Fulford, 1999). At that time, most came from Italy, Southern Gaul and Spain (Mann, 1983; Millett, 1999), with only a few born to citizens living in Britain. The latter would have gradually increased throughout the Roman period. The hinterland of Gloucester is difficult to define (Hurst, 1999; Reece, 1999), but probably included areas west of the River Severn, east of the Cotswold escarpment, and north and south along the Vale of Gloucester. While the epigraphic record hints at migration into and away from the site and surrounding areas (Birley, 1979; McWhirr, 1981), the limited number of Romano-British inscriptions makes the examination of human remains a far more promising avenue for research.

Excavations at 120-122 London Road, Gloucester (2004-2006) revealed part of a Roman cemetery containing cremations and inhumations dating from the 1 st to the 4 th century AD (Simmonds et al., 2008). The most striking feature uncovered by the excavation was a 2nd century mass burial pit containing the remains of at least 91 individuals, thought to have been placed, somewhat haphazardly, into the pit in a single event. Osteological analysis suggests no significant differences between the individuals buried in the pit and those in discrete graves in the cemetery in terms of the incidence of disease or trauma, or sex, although there was an excess of young adults in the mass burial pit (Márquez-Grant and Loe, 2008). 
The excavators interpreted the pit individuals as "victims of a catastrophic occurrence that resulted in the need to dispose of large numbers of corpses with no opportunity for the normal formalities..." (Simmonds et al., 2008: 140), most likely a serious epidemic. This study examines whether the isotopic evidence supports this interpretation, and more broadly, asks how diverse in terms of their geographical origins and diet, the population of 2 nd century Gloucester really was.

\section{Isotopic analysis of human remains}

The main principle of isotope analysis of human remains for reconstructing residential mobility or diet is that the natural abundance of different isotopes in items of food or drink varies systematically, according to the environments they are produced in. These "isotopic signatures" contained in food are incorporated into the skeletal tissues of consumers which, on analysis, allow the reconstruction of main dietary sources and, provided that foodstuffs are predominantly sourced locally and not imported, the characterisation of the places of residence of individuals at the time of tissue formation (Sealy, 2001).

\subsection{Dietary reconstruction: carbon and nitrogen isotope analysis.}

Carbon stable isotope ratios $\left(\delta^{13} \mathrm{C}\right)$ are used in dietary reconstruction to distinguish between major types of food, in particular between plants following the $\mathrm{C} 3$ and $\mathrm{C} 4$ photosynthetic pathways and the products of animals feeding on these plants, or, especially in areas of temperate climate where $\mathrm{C} 4$ plants are rare, between terrestrial, $\mathrm{C} 3$-plant based, and marine foods. $\delta^{13} \mathrm{C}$ data are complemeted by nitrogen stable isotope ratios $\left(\delta^{15} \mathrm{~N}\right)$ which give an indication of the trophic level an organism is feeding at and therefore allow an estimation of the relative importance of plant and animal products in the diet (Ambrose, 1993; Schwarcz \& Schoeninger, 1991; Sealy, 2001). Carbon and nitrogen stable isotope analysis for dietary reconstruction is usually conducted on bone or dentine collagen. Most collagen is synthesised directly from dietary protein ("protein routing") and its isotopic composition is therefore biased towards the main protein sources, rather than reflecting diet as a whole (see Jim et al., 2006). Different types of bone have different collagen turnover times, and reflect diet at different stages in an individual's life. Dentine preserves the isotopic signature of diet at the time of tooth formation in childhood, while the collagen in the shafts of long bones has been formed over several decades with a significant proportion laid down in adolescence. Ribs, which are relatively thin and contain a greater proportion of cancellous bone give a shorterterm record of diet - still likely several years, although good empirical data is scarce (Sealy et al., 1995; Wild et al., 2000; Hedges et al., 2007). Carbon and nitrogen stable isotope analysis has been previously used to reconstruct the diet of Roman populations in Britain (Richards et al., 1998; Fuller et al., 2006; Müldner and Richards, 2007), Italy (Prowse et al., 2004, 2005; Craig et al., 2009) and elsewhere (Keenleyside, 2009; Dupras and Tocheri, 2007). The results illustrate not only the environmental diversity across the Roman Empire but also that contributions of animal and marine protein to the diet varied according to sex, age or social status. 


\subsection{Reconstructing Mobility: strontium and oxygen isotope analysis}

Strontium and oxygen form two independent isotopic systems, reflecting local geology and climate, respectively. Provided that an individual's diet is dominated by local food and drink, strontium and oxygen isotope ratios can be used to characterise their place of childhood residence.. Biosphere ${ }^{87} \mathrm{Sr} /{ }^{86} \mathrm{Sr}$ vary mainly according to the type and age of the underlying bedrock, although contributions from sources such as geological drift, dust or rainwater, can be significant (Bentley, 2006; Montgomery et al., 2007). The ${ }^{87} \mathrm{Sr} /{ }^{86} \mathrm{Sr}$ of tooth enamel reflect the average isotope composition of childhood food intake (Montgomery, 2002; Bentley, 2006). In humans, the $\delta^{18} \mathrm{O}$ of skeletal phosphate is controlled by the isotope compostion of the drinking water, although water contained in food and atmospheric oxygen are known to make smaller contributions (Longinelli 1984; Luz et al. 1984; see White et al. 1998, 2004; Daux et al. 2008). Virtually all drinking water is derived from precipitation (as rain or snow). The isotopic composition of precipitation depends on the source water of the precipitation, the distance from the coast, altitude, temperature of precipitation and local climate conditions (Darling, 2004; Darling et al., 2006), Therefore in Western Europe the mean $\delta^{18} \mathrm{O}$ of precipitation decreases from west to east and to a lesser degree from south to north (Lecolle 1885). The preferred analyte for strontium and oxygen isotope analysis of archaeological samples is dental enamel, which preserves the isotopic signature of the environment at the time of tooth formation in childhood, and is largely resistant to diagenetic change (Hillson, 1996, Hoppe et al., 2003). Most previous applications of these methods for Roman archaeology have used either oxygen (Prowse et al., 2007) or strontium isotopes (Schweissing and Grupe, 2003; Perry et al., 2008) to investigate mobility. A combined approach by Evans et al. (2006a) on the cemetery of Lankhills (Hants., U.K.) established considerable diversity of geographic origins which, interestingly, did not always correlate with expectations based on the archaeological evidence. 


\subsection{Establishing a 'local' strontium signature.}

The geology of the Gloucester is complex, both in terms of outcrop patterns and geological age. The city of Gloucester lies within the Vale of Gloucester (Fig. 2), a broad expanse of early Jurassic, Lower Lias, mudstones which are overlain, in part, by Quaternary alluvia, undifferentiated river terrace deposits and Holocene to recent tidal flat deposits. The Vale is bordered by three geographic and geologically distinct areas: the Cotswold Hills to the south and southeast (dominated by early Jurassic limestones and subordinate mudstones), the Forest of Dean to the west (Palaeozoic (Silurian to Carboniferous) sandstones and mudstones), and the Malvern Hills to the north (Precambrian and Cambrian igneous and meta-igneous rocks and Palaeozoic sediments). The Malverns are separated from the Vale of Gloucester by an expanse of Triassic mudstones which are, in parts, covered by a "head" of post-glacial rubble drift. The bedrock substrates of the region within a $30 \mathrm{~km}$ radius of Gloucester $\left(\sim 2823 \mathrm{~km}^{2}\right)$, therefore, range from Precambrian (>545 Ma) Malvern meta-igneous to the Oxford Clay of Jurassic age ( 154 Ma).

This complex geology is a strong indication that the strontium isotope signatures within the study area will vary widely. Strontium isotope measurements of waters in the general Gloucester area, though sparse, provide a guide for the biosphere values derived from the different lithologies. Mineral water data from aquifers in the Cotswold limestone gave a value of 0.7084 (Montgomery et al., 2006). ${ }^{87} \mathrm{Sr} /{ }^{86} \mathrm{Sr}$ from water samples from the Malverns range from 0.7094 to 0.7133 (Spiro et al., 2001; Montgomery et al., 2006).

Various approaches have been used to constrain the bio accessible ${ }^{87} \mathrm{Sr} /{ }^{86} \mathrm{Sr}$ regions of interest for population origins and movement. These include direct measurements of water, soil, rock, human and faunal remains or vegetation (Price et al., 2002; Bentley et.al., 2004, Bentley and Knipper, 2005 and Evans et.al. 2009), and estimations based on published values for geological substrates of similar age and rock type (Beard and Johnson 2000). While measurements of archaeological fauna may be suited to determining the local strontium range they are not always readily available. ${ }^{87} \mathrm{Sr} /{ }^{86} \mathrm{Sr}$ in vegetation provides a direct biosphere measurement, are readily available and samples can be targeted easily in areas of interest, in this case the different lithologies encountered in the Gloucester region. Assuming that a given population is likely to resource most of its food within a single days travel, a study area within $30 \mathrm{~km}$ of Gloucester city centre was chosen for vegetation sampling.

\subsection{Establishing a UK oxygen isotope range}

The oxygen isotope composition of modern freshwater in the UK is relatively well known, with $\delta^{18} \mathrm{O}$ between $-9.0 \%$ and $-4.5 \%$, with the highest values $(>\sim-5.0 \%$ o $)$ being isolated to the Outer Hebrides and the extreme west coast of Cornwall (Darling and Talbot, 2003; Darling et al., 2003). Gloucester itself is within Darling et al.'s (2003) -7.0 to -7.5\%o contour. Drinking waters measured in the area gave mean values of $-7.0 \%$ (Darling, pers. comm.). On the European continent and around the Mediterranean coast, $\delta^{18} \mathrm{O}$ values for precipitation range from <-10.0\% to c. $-3.0 \%$ (Bentley and Knipper, 2005; IAEA/WISER, 2008; Lecolle et al., 1985; Longinelli and Selmo, 2003; Lykoudis and Argiriou, 2007). 
Oxygen undergoes fractionation through metabolic processes and relating the isotopic composition of skeletal phosphate $\left(\delta^{18} \mathrm{O}_{\mathrm{p}}\right)$ directly to climate regions requires conversion to approximate drinking water values $\left(\delta^{18} \mathrm{O}_{\mathrm{dw}}\right)$ using one of the available regression equations (Longinelli 1984; Luz et al. 1984; Levinson et al. 1987; Daux et al. 2008). Since there is no general agreement over which of these equations is the most appropriate, and also because of the relatively large statistical error associated with each (see Daux et al., 2008), we have derived a current best estimate for $\delta^{18} \mathrm{O}_{\mathrm{p}}$ values of humans growing up in Britain from available oxygen isotope data for individuals with "local" ${ }^{87} \mathrm{Sr} /{ }^{86} \mathrm{Sr}$ from various sites across the UK (see appendix below for details). The $2 \sigma$ range of these data is $16.8 \%$ o to $18.6 \%$ o (mean 17.7 $\pm 0.9 \%$ for 57 individuals from nine sites), giving a broad UK baseline. To further aid in the interpretation of our data, we are using $\delta^{18} \mathrm{O}_{\mathrm{dw}}$ values calculated by the equation of Levinson et al. (1987) with a method bias correction of 1.4, as we have found that drinking water values computed in this way for probable locals from various UK sites provided a very good match with "expected" (modern) freshwater values for the same area (see appendix below for details).

The balance of palaeoclimate evidence indicates that Roman Britain was somewhat warmer than today, before a climatic downturn, probably from the $5^{\text {th }}$ century AD (Dark, 2000: 19ff.). Increased temperatures may translate into higher oxygen isotope ratios of meteoric water and, by implication, more positive $\delta^{18} \mathrm{O}_{\mathrm{p}}$ of humans growing up in Roman Britain than in other, cooler, time periods. However, the significance of relatively minor temporal shifts in climate for mobility studies is currently difficult to gauge. In a diachronic study of humans living in Lorraine (northeast France) from the $4^{\text {th }}$ century AD to the present day, Daux et al. (2005) found no significant differences in $\delta^{18} \mathrm{O}_{\mathrm{p}}$ between time periods, not even in relation to the "Little Ice Age", the most significant cooling event of the late Holocene. They suggest that oxygen isotope levels in skeletal phosphate are either not sensitive to small variations in surface temperature, or that temperature-induced changes are offset by other factors, such as shifts in seasonal rainfall patterns (see Fricke \& O'Neil, 1999). Indeed, extended periods of dry summers as they are suggested for Roman Britain from documentary sources and peatland evidence (Dark, 2000: 19f.; Swindles et al., 2009) could have had just such an effect (see Daux et al., 2005; Fricke \& O'Neil, 1999). While the issue of climate fluctuations for human mobility studies is therefore far from solved, for the moment and with caution we make the assumption that modern water values and human $\delta^{18} \mathrm{O}_{\mathrm{p}}$ from other time-periods (see Appendix) are valid comparisons for our Romano-British data.

\section{Materials and Methods}

\subsection{Bone and tooth sample preparation}

The London Road site comprised 64 individuals from inhumation graves in the main cemetery, and a minimum of 91 individuals in the mass burial pit. Of these, 73 were articulated skeletons (Márquez-Grant and Loe, 2008). Fifty human bones (rib or long bones) and 11 faunal remains were sampled for carbon and nitrogen isotope analysis. Dentinal collagen, usually from the root immediately below the cemento-enamel junction, was also extracted from the teeth sampled for oxygen and strontium isotope determinations. For these, the teeth of 21 individuals were selected, 10 were from the main cemetery, and 11 from the 
mass grave (Table 1). Permanent second or third molars were sampled, representing an age at crown formation of 3-7 years (M2) and 9-13 years (M3), respectively. Root formation occurs between c. 7 to c. 14 years (M2) and c. 13 to c. 19 years (M3) (Hillson, 1996; Smith, 1991).

Collagen was extracted using a modified Longin (1971) method as described by Britton et al. (2008). Collagen preservation at the site and particularly in bones from the mass-grave was very poor. Only 11 human and nine faunal bone yielded products for analysis. Dentinal collagen was much better preserved, with 20 dentine samples providing data with acceptable quality indicators (see DeNiro, 1985; van Klinken, 1999). Enamel samples were prepared for strontium and oxygen isotope analysis following methods by Montgomery (2002) and O'Neil et al. (1994), as described in Evans et al. (2006a). Two samples of dentine were also processed for determination of ${ }^{87} \mathrm{Sr} /{ }^{86} \mathrm{Sr}$ by the same method as the enamel. No attempt was made to remove diagenetic strontium from the dentine samples as these are used in order to help characterize the isotope composition of the local burial soil (see Montgomery et al., 2007 and below).

\subsection{Establishing strontium isotope parameters: plant sample preparation}

Grass and/or herbaceous plants were sampled at 34 sites from around the Gloucester area, to provide a comprehensive representation of the geologic periods, and major rock and drift types. Assuming that most foods available in Roman Gloucester were sourced from within one day's travel of the town, all samples were obtained from within a 30km radius of the modern city (Fig. 2, Table 2). Two litres of vegetation were collected at each site over several square meters. In order to avoid potential anthropogenic contamination, the sampling sites were chosen away from major roads, at least $10 \mathrm{~m}$ away from small roads or track ways, and avoiding currently cultivated fields. All vegetation samples were dried at $40^{\circ} \mathrm{C}$ for 36 hours. Approximately $25 \%$ of the dried plant material was sub-sampled. Stems were removed and leaves were hand-crushed, coarsely sieved and stored in clean plastic bags for later analysis. The resulting samples ranged in weight from c. 25 to c. $50 \mathrm{~g}$. In a clean laboratory, approximately 0.2 grams of crushed and sieved plant material was placed into clean, dry PFA Teflon vessels to which $6 \mathrm{ml}$ Teflon distilled $3 \mathrm{M} \mathrm{HNO}_{3}$ was added. The samples were left uncovered to allow release of early gas production before tightly sealing. The vessels were placed in a MARSXpress ${ }^{\mathrm{TM}}$ low pressure microwave digestion unit, set to ramp up to and hold the sample at $170{ }^{\circ} \mathrm{C}$ for 10 minutes. Once cooled, the dissolved plant solution was transferred into $22 \mathrm{ml}$ clean Savillex beakers and taken to dryness over a hotplate. To complete the dissolution, $1 \mathrm{ml} 8 \mathrm{M} \mathrm{HNO}_{3}$ was added to the sample and taken to dryness. The sample was then converted to chloride form with $1 \mathrm{ml}$ of $6 \mathrm{M} \mathrm{HCl}$ and taken up in $2.5 \mathrm{M} \mathrm{HCl}$. Strontium was collected using conventional, Dowex ${ }^{\circledR}$ resin ion exchange methods.

\subsection{Isotope-ratio mass spectrometry}

Isotopic measurements of $\delta^{13} \mathrm{C}$ and $\delta^{15} \mathrm{~N}$ were performed in duplicates by Continuous Flow Isotope Ratio Mass Spectrometry (CF-IRMS). Analytical error $( \pm 0.2 \%, 1 \sigma)$ was calculated from repeat measurements of internal standards and internationally certified reference material (USGS-40). Analysis of $\delta^{18} \mathrm{O}_{\mathrm{p}}$ was by CF-IRMS using the method of Venneman et al. (2002). Each sample was analysed in triplicate. Sample reproducibility averaged at $\pm 0.25 \%$ o $(2 \sigma)$ (see Table 1 for individual samples). External batch reproducibility 
was $0.15 \%$ o $(n=6,1 \sigma)$. All data were corrected to an internal value of $+21.7 \%$ VSMOW for NBS120C (see Appendix for further information).

The strontium isotope composition and concentrations were determined by Thermal Ionisation Mass spectrometry (TIMS) using a ThermoFinnigan Triton multi-collector mass spectrometer. Samples were run using single Re filaments loaded with TaF activator (after the method of Birck, 1986). All samples were determined to an internal precision of better than $\pm 0.000012(2 \sigma)$. The reproducibility of the international standard for ${ }^{87} \mathrm{Sr} /{ }^{86} \mathrm{Sr}$, NBS987, was $\pm 0.00006(1 \sigma, n=5)$. All strontium isotope ratios were corrected to a NBS 987 standard value of 0.710250 . Strontium procedural blanks were between 20-250pg (the higher values were from the plant microwave dissolution) and hence, provided a negligible contribution.

\section{Results}

Isotopic measurements for bone and dental tissues of humans and animals are presented in Tables 1 and 3. Strontium isotope data for the biosphere plant samples are given in Table 2. All individuals with sample numbers greater than 1500 are from the mass burial pit.

\subsection{Carbon and nitrogen stable isotope evidence for diet}

The $\delta^{13} \mathrm{C}$ ratios for human bone samples $(\mathrm{n}=11)$ range between $-20.5 \%$ and $-18.8 \%$ (mean $-19.7 \pm 0.5 \%$ ), $1 \sigma$ ). Nitrogen isotope ratios ranged between $10.2 \%$ and $12.5 \%$ with a mean of $11.1 \pm 0.7 \%$. Results from the dentine samples are very similar $\left(\delta^{13} \mathrm{C}\right.$ range: $-20.3 \%$ o to $-18.8 \%$; mean: $-19.8 \pm 0.5 \%$; $\delta^{15} \mathrm{~N}$ : $8.8 \%$ o to $12.6 \%$, mean: $11.3 \pm 1.0 \%$ o). Herbivore carbon and nitrogen isotope data average at $-21.6 \pm 0.3 \%$ and $6.4 \pm 0.6 \%$ o $(1 \sigma)$ (Table 3; Fig. 3 ). There are no significant differences in $\delta^{15} \mathrm{~N}$ ratios between dentinal and bone collagen $\left(\mathrm{t}_{(29)}=\right.$ 4.6, $\mathrm{p}=0.65)$, or between data from second and third molars $\left(\mathrm{t}_{(18)}=-1.69, \mathrm{p}=0.11\right)$, suggesting that in all cases weaning had occurred before tooth formation commenced (see Wright and Schwarcz, 1998).

The dietary data from Gloucester are directly comparable to the Romano-British dataset from York, another colonia town in Roman Britain (Müldner \& Richards, 2007). In keeping with other evidence for diet in the British provinces (Dobney et al., 1999; Cool, 2006), these data can be interpreted in terms of a terrestrial $\left(C_{3}\right.$-based $)$ diet, probably with a relatively large contribution from animal protein (see Müldner \& Richards, 2007 for discussion). A number of individuals in the Gloucester assemblage have $\delta^{13} \mathrm{C}$ values that are elevated by more than $2 \%$ over the herbivore baseline $\left(\delta^{13} \mathrm{C}>19.6 \%\right.$ ), an offset which is unusually large for a single trophic level effect, especially when bone collagen values are compared directly (see Bocherens and Drucker, 2003). At York, and with the benefit of a larger sample size, similar values were interpreted as reflecting a small contribution of marine protein to the diet (Müldner \& Richards, 2007). For Gloucester, however, comparison with the available oxygen isotope evidence suggests a different explanation (see discussion below).

There are no significant differences in dentinal collagen isotope composition between individuals buried in discrete graves or the mass-grave (independent sample t-test: $\mathrm{t}_{(18)}=-0.46$, $\mathrm{p}=0.65$ for $\delta^{13} \mathrm{C} ; \mathrm{t}_{(18)}=-0.38, \mathrm{p}=0.71$ for $\left.\delta^{15} \mathrm{~N}\right)$, between males and females $\left(\mathrm{t}_{(15)}=-1.21\right.$, $\mathrm{p}=0.24$ for $\delta^{13} \mathrm{C} ; \mathrm{t}_{(15)}=-1.74, \mathrm{p}=0.10$ for $\delta^{15} \mathrm{~N}$ ) or different age groups (One-way ANOVA: 
$\mathrm{F}_{(3,17)}=1.75, \mathrm{p}=0.19$ for $\delta^{13} \mathrm{C} ; \mathrm{F}_{(3,17)}=0.36, \mathrm{p}=0.78$ for $\left.\delta^{15} \mathrm{~N}\right)$. No statistical tests were carried out on the bone collagen data due to small sample sizes.

\subsection{Strontium and oxygen isotope evidence for mobility}

\subsubsection{Biosphere ${ }^{87} \mathrm{Sr} /{ }^{86} \mathrm{Sr}$ data}

Strontium isotope data for modern vegetation samples range from 0.7077 to 0.7162 , with a mean of $0.7109 \pm 0.0045(2 \sigma, n=34)$ for plants growing within a $30 \mathrm{~km}$ radius of the site, demonstrating a very wide range of ${ }^{87} \mathrm{Sr} /{ }^{86} \mathrm{Sr}$ for such a small area $\left(\mathrm{c} .2,820 \mathrm{~km}^{2}\right)$. For comparison, the strontium isotope range measured for mineral water from 26 sites across England and Wales (not Scotland) was 0.7077 to 0.7139 (Montgomery et al., 2006).

The ${ }^{87} \mathrm{Sr} /{ }^{86} \mathrm{Sr}$ data for the plant samples in comparison with geological substrates are shown in Figure 2. Although there is the expected trend of increasing biosphere ${ }^{87} \mathrm{Sr} /{ }^{86} \mathrm{Sr}$ values with the age of the underlying bedrock, there is substantial variation among rock types within and between geologic time-periods. ${ }^{87} \mathrm{Sr} /{ }^{86} \mathrm{Sr}$ values for vegetation growing over sandstone tend to be the most radiogenic, with decreasing values in the order mudstones /argillaceous rocks, limestones with an argillaceous component and limestones without an argillaceous component. ${ }^{87} \mathrm{Sr} /{ }^{86} \mathrm{Sr}$ data for the area around Malvern Hills are spread most widely (Fig. 5) and reveal the effects of land slip and drainage over geologically complex, steeply sloping terrain. Where plants grow on or close to rubble drift ('Head') their isotopic values are strongly influenced by the source of the drift.

Although the overlap between different areas is considerable, the modern biosphere samples allow us to broadly characterize strontium isotope ranges typical for different parts of the study region (Figs. 2 and 5). Values within the Vale of Gloucester and on tidal flood deposits of the river Severn gave a mean of $0.7095 \pm 0.0012(2 \sigma, \mathrm{n}=8) .{ }^{87} \mathrm{Sr} /{ }^{86} \mathrm{Sr}$ values for the two dentine samples (GLR1216, 1560), which are expected to have taken up diagenetic strontium from the burial environment and therefore to reflect the isotopic composition of the local soil (see Budd, et al., 2000; Montgomery et al., 2007), are in agreement with these data ( 0.7093 and 0.7092 , see Table 1). Vegetation from the Cotswolds gave an overall mean of $0.7088 \pm 0.0025(2 \sigma, \mathrm{n}=8)$. However, the mean value for plants growing on the dominating Jurassic Limestone, $0.7080 \pm 0.0005(2 \sigma, n=5)$ differed from those on limestones with an argillaceous component (G-V-009 and G-V-010, 0.7098, 0.7090), with the latter values more similar to those measured for the Vale of Gloucester. To the west of the River Severn and around the Forest of Dean, isotope ratios for bio-accessible strontium over Carboniferous and Devonian sandstones gave a mean of $0.7123 \pm 0.0015(2 \sigma, n=4)$. This contrasts with a value of 0.7098 (G-V-13) for vegetation growing on Triassic mudstone near-by. The Malvern Hills area to the north produced the most variable biosphere values. They range between 0.7101 (Palaeozoic silt- and mudstone; G-V-032) and 0.7162 (Precambrian meta-igneous rock; G-V026). Overall, the vegetation samples from this area gave a mean of $0.7128 \pm 0.0040(2 \sigma$, $\mathrm{n}=13)$.

\subsubsection{Human ${ }^{87} \mathrm{Sr}{ }^{86} \mathrm{Sr}$ data}

The enamel ${ }^{87} \mathrm{Sr} /{ }^{86} \mathrm{Sr}$ ratios cover a broad range from 0.7088 to 0.7134 (Table 1; Fig. 5). All strontium isotope ratios fall within the range of bio-accessible strontium within $30 \mathrm{~km}$ of Gloucester. The majority of the individuals (16 out of 21), plot within the ${ }^{87} \mathrm{Sr} /{ }^{86} \mathrm{Sr}(0.7077$ to 0.7109 ) range for vegetation growing over the Jurassic terrains of the Vale of Gloucester 
and the Cotswolds, although three of these (GLR1181, 1328, 1546), display values that also overlap between Jurassic Mudstones and Palaeozoic sandstones (0.7106, 0.7106 and 0.7109, respectively). ${ }^{87} \mathrm{Sr} /{ }^{86} \mathrm{Sr}$ values for the remaining six individuals are more radiogenic and compatible with coming from older Palaeozoic, Precambrian or rubidium rich, igneous terrains. Three individuals (GLR1131, 1364, 1541) have values compatible with bioaccessible strontium measured for the Palaeozoic terrains to the west of the River Severn, and with bottled water from Silurian mudrocks in Wales (Montgomery et al., 2006). The very high values for GLR1518 and GLR1561 $(0.7130,0.7135)$ are both compatible with the values reported for the Malverns or similar Precambrian volcanic rocks, as well as head deposits down-slope to the east of the Malvern Hills.

Statistical comparison between individuals from discrete burials with those from the mass grave revealed no significant differences in strontium isotope composition (independent sample t-test: $\left.\mathrm{t}_{(19)}=-0.926 ; \mathrm{p}=0.368\right)$. Similarly, no significant differences were observed between males and females $\left(\mathrm{t}_{(13)}=-0.799, \mathrm{p}=0.134\right)$, or different age groups (One-way ANOVA $\left.F_{(3,17)}=0.54, p=0.66\right)$.

\subsubsection{Human $\delta^{18} \mathrm{O}$ data.}

The enamel phosphate oxygen isotope ratios $\left(\delta^{18} \mathrm{O}_{\mathrm{p}}\right)$ in the study sample range from $17.1 \%$ to $19.2 \%$. Equivalent drinking water values $\left(\delta^{18} \mathrm{O}_{\mathrm{dw}}\right)$ calculated using Levinson $e t$ al.'s (1987) equation and taking into account analytical method bias (see appendix), range from $-8.1 \%$ to $-3.5 \%$. Based on kernel density estimations (RSC, 2006; see Fig. 4), these data can be split into two groups, at $18.4 \%$ o $(-5.1 \%)$ : into a larger group $(n=14)$ with $\delta^{18} \mathrm{O}_{\mathrm{p}}$ ratios between $17.1 \%$ and $18.4 \%$ (mean $17.7 \pm 0.9 \%, 2 \sigma)$ and a smaller group $(n=7)$ with higher $\delta^{18} \mathrm{O}_{\mathrm{p}}$ signatures between $18.6 \%$ to $19.2 \%$ (mean $18.9 \pm 0.4 \%$ ), suggesting origins in a warmer, more coastal or possibly more arid climate. The differences between these two groups are statistically significant (Mann-Whitney test: $\mathrm{U}_{(19)}<0.001, \mathrm{Z}=-3.66, \mathrm{p}<0.001$ ). All individuals in the first group fall within the $\delta^{18} \mathrm{O}_{\mathrm{p}}$ range of $16.8-18.6 \%$ which we use as a current best estimate for the range of values expected for individuals growing up in the UK (see above and appendix). The individuals in the second group are outside this range, with the exception of GLR1520 which is at the cut-off point of 18.6\%. Using the corrected Levinson equation to calculate drinking water values, only four individuals in this second group (GLR1360, 1565, 1546, 1216) fall strictly outside the expected range for UK water (>-4.5\%); however, the remaining individuals (GLR1520, 1561, 1560) if from the UK, are only consistent with water values from extreme western Britain (>-5.0\%; see Darling et al., 2003).

When the oxygen stable isotope data are compared with $\delta^{13} \mathrm{C}_{\text {dentine }}$ values from the same teeth, it is apparent that individuals from the second group (with higher $\delta^{18} \mathrm{O}_{\mathrm{p}}$ ) are also enriched in ${ }^{13} \mathrm{C}$ over the others, with GLR1520 (the individual at the cut-off point for $\delta^{18} \mathrm{O}_{\mathrm{p}}$ ) displaying marginally lower $\delta^{13} \mathrm{C}$ than the others (Figure 6). Again, the difference between the two groups is significant (Mann-Whitney test: $U_{(18)}=1.50, Z=-3.39, p<0.001$ ) This pattern may be best explained by the climate-driven gradient in the carbon isotope composition of $\mathrm{C}_{3}$ plants across Europe, which gives individuals on terrestrial $\mathrm{C}_{3}$ diets in, for instance, the Mediterranean on average 1-2\%o higher $\delta^{13} \mathrm{C}$ ratios than humans eating the same foods in the UK (van Klinken et al., 2000). The positive correlation between carbon and oxygen isotope 
ratios $(\mathrm{r}=0.68, \mathrm{p}=0.001)$ therefore lends further support to the argument that several individuals buried in Roman Gloucester spent their childhood in a warmer climate.

Statistical comparison of oxygen isotope ratios between individuals from the cemetery and the mass-grave show no significant differences $\left(\mathrm{t}_{(19)}=-0.621, \mathrm{p}=0.542\right)$, neither do comparison between males and females $\left(\mathrm{t}_{(13)}=1.153\right.$; $\left.\mathrm{p}=0.270\right)$ or different age groups (Oneway ANOVA: $\left.\mathrm{F}_{(3,17)}=0.58, \mathrm{p}=0.64\right)$.

\section{Discussion}

\subsection{Purpose of the Mass-Grave}

Statistical analyses revealed no differences between mass-grave and cemetery burials, age or sex for any of the isotopes tested, suggesting that the individuals in the mass-grave were a random sample of the population of Roman Gloucester. Our results are therefore consistent with the conclusions drawn by Simmonds et al. (2008) based on osteological evidence, that the mass-grave was constructed after a catastrophic event, such as an epidemic.

Historical sources report a number of epidemic diseases that afflicted the Roman Empire in the first centuries AD, but they do not state if the British provinces were affected. The dating of the mass burial pit to the late $2^{\text {nd }}$ century $\mathrm{AD}$ places it later than the main cemetery and corresponds with the Antonine Plague, that began in AD165 in Mesopotamia, but quickly spread to Rome, the Rhine and Gaul (Cartwright and Biddiss, 2004; Gilliam, 1961; Jackson, 1988; McNeill, 1977). The plague may have been an outbreak of smallpox (Littman and Littman, 1973), and its impact on the Roman world is still debated (Greenburg, 2003). Although a connection between the Antonine Plague and the mass-grave from London Road is by no means certain, it seems very likely that it was an epidemic of a similar nature which afflicted the population of Glevum.

\subsection{Childhood origins of the people of Gloucester}

Identifying migrants through strontium and oxygen isotope data requires the definition of the range of values that are consistent with a local upbringing (Bentley et al., 2004). This is generally more difficult for oxygen isotopes. Unlike strontium, oxygen is fractionated by metabolic processes and the different fluxes of oxygen into and out of the body which ultimately determine the oxygen isotope composition of skeletal phosphate are complex and variable between individuals (Luz et al., 1984; Luz and Kolodny, 1985; Bryant and Froelich, 1995; Kohn, 1996; White et al., 2004). The range of "natural" variation in $\delta^{18} \mathrm{O}_{\mathrm{p}}$ that can be expected in a stationary population consuming drinking water of the same isotopic composition is, therefore, currently unknown. In the absence of a baseline at Gloucester derived from human $\delta^{18} \mathrm{O}$ values of probable locals (see Evans et al., 2006a; Prowse et al., 2007), we currently do not attempt constraining the oxygen isotope data beyond what we suggest as the current best estimate of a UK range (17.7 $0.9 \%$, see appendix). Nevertheless, plotting the range of modern drinking water values for the Gloucester area (-6.5\% to $-7.5 \%$; Darling et al., 2003; Darling pers. comm.) with calculated $\delta^{18} \mathrm{O}_{\mathrm{dw}}$ for the human samples gives at least a broad indication of where local human values would be expected (Figure 5). This approach allows some relative statements about the human data (see below). 
Since oxygen isotopes mainly work on broad geographical scales, strontium isotopes are often employed to define local values in more detail (for example Evans et al., 2006a). Because of the complex geology of the Gloucester area, however, these also proved difficult to use: Biosphere ${ }^{87} \mathrm{Sr} /{ }^{86} \mathrm{Sr}$ within $30 \mathrm{~km}$ of Gloucester encompass the entire range of strontium isotope values previously measured for mineral waters from England and Wales (Montgomery et al., 2006). It is therefore unsurprising that the ${ }^{87} \mathrm{Sr} /{ }^{86} \mathrm{Sr}$ of all 21 individuals in the sample can be found within this $30 \mathrm{~km}$ radius. This does not, of course, mean that they are local, as they could have equally moved from other places with consistent strontium values. When assessing the hinterland of Glevum, it is apparent that the majority of individuals (10 out of 14 with "UK-range" $\delta^{18} \mathrm{O}_{\mathrm{p}}$ ratios, see above) have ${ }^{87} \mathrm{Sr} /{ }^{86} \mathrm{Sr}$ that are consistent with foods derived from the Vale of Gloucester and the Cotswolds, within $\sim 10 \mathrm{~km}$ around the city (Figs. 2 and 5) and it seems likely that these areas provided the bulk of the food supply for Roman Gloucester. Consequently, it may be the simplest explanation for individuals with higher ${ }^{87} \mathrm{Sr} /{ }^{86} \mathrm{Sr}(>0.7110)$ that they did not spend their childhood in Gloucester, rather than that they just happened to predominantly consume foods which came into town from further afield.

The $\delta^{18} \mathrm{O}$ of the four individuals in question (GLR1131, 1364, 1518, 1541) fall either side of the projected Gloucester drinking water range (Fig. 5). Although it is difficult to assess whether these data are still consistent with an upbringing in the Gloucester area, we can at least derive from this that origins for individuals GLR1518 and 1364, with more enriched $\delta^{18} \mathrm{O}$, should be sought, if not in the radiogenic terrains around Gloucester, then in "warmer" areas to the West (i.e. Wales) and southwest (areas in modern Somerset, Devon or Cornwall). Accordingly, GLR1131 and 1541, with more depleted $\delta^{18} \mathrm{O}$, would have moved from older rocks in "cooler" areas to the north and east, i.e. central and Northern England or even Scotland (see Darling et al., 2003; Montgomery et al., 2006; BGS Map, 2007). Alternatively, there are of course many other areas on the European continent or even further afield, within the confines of the Roman Empire, that could match the observed isotope data (Asch, 2005; IAEA/WISER, 2008).

More diverse origins for the Gloucester population are indeed suggested by the oxygen isotope data. Six individuals have $\delta^{18} \mathrm{O}_{\mathrm{p}}$ ratios that are outside our current estimate for a UK range. Although two of these (GLR1560, 1561) fall only just out of this range, kernel density estimations and the evidence from carbon stable isotope analysis independently suggest they should be seen as one group with the remaining four (GRL1216, 1360, 1546, 1565) which have values $\geq 19 \%$. A seventh individual (GLR1520) could also be included on the basis of the kernel density estimations, though not, perhaps, the carbon isotope evidence (see above and Figs. 4 and 6). The $\delta^{18} \mathrm{O}_{\mathrm{dw}}$ of these seven individuals are consistent only with the westernmost parts of Cornwall or Scotland or are even more ${ }^{18} \mathrm{O}$ enriched (Figure 5; Darling et al., 2003). Given the areas of Roman influence in the British Isles, the probability of these being from Britain is small and an origin abroad is more likely.

Our ability to constrain the possible geographical origin of these individuals is currently hampered by the scarcity of directly comparable human isotope data from possible regions of origin, the availability and spatial resolution of data on drinking water $\delta^{18} \mathrm{O}$ and 
biosphere ${ }^{87} \mathrm{Sr} /{ }^{86} \mathrm{Sr}$ for these areas, as well as the error associated with available phosphate oxygen to drinking water conversion equations (see Daux et al, 2008). The suggested places of origin given below are therefore based on 'best matches' with currently available data. Despite its latitude, much of Britain enjoys a relatively mild and coastal climate, largely because of the Gulf Stream. Average drinking water $\delta^{18} \mathrm{O}$ for Britain therefore overlap not only with geographically close areas such as northern France, the Low Countries and northwest Germany, but also with those of other European regions that are commonly thought of as "warmer", such as Southern Europe and the Mediterranean (IAEA/WISER, 2008; Longinelli and Selmo, 2003; Prowse et al., 2007; Lykoudis and Argiriou, 2007). Calculated $\delta^{18} \mathrm{O}_{\mathrm{dw}}$ ratios of the suggested non-UK individuals range from $-4.7 \%$ to $-3.5 \%$ which are consistent with many areas of the Mediterranean coast. With a maximum $\delta^{18} \mathrm{O}_{\mathrm{p}}$ of $19.2 \%$, however, they are still significantly lower than values reported for humans from a hot and arid region like the Nile Valley, most of which are in excess of 21\%o (Iacumin et al., 1996; White et al., 2004 [although these data were produced using different methods and it is therefore unclear how they compare to our own in absolute terms, see appendix]). Origins in relative proximity to the coast would also be consistent with the strontium isotope evidence for most of the seven suggested non-UK individuals. Five (GLR1216, 1360, 1520, 1560, 1565) have ${ }^{87} \mathrm{Sr} /{ }^{86} \mathrm{Sr}$ between 0.7090 and 0.7097 which are close to the value for modern seawater ( 0.7092). These data are compatible with terrains over Mesozoic sediments of marine origin or, more generally, with foods derived from coastal zones where marine strontium has a significant effect on biosphere ${ }^{87} \mathrm{Sr} /{ }^{86} \mathrm{Sr}$ (Montgomery et al., 2007). The remaining two individuals (GLR1546, 1561) have more radiogenic values, both in excess of 0.7100 but relatively far apart ( 0.7109 and 0.7135 , respectively). These suggest childhoods in different areas of Palaeozoic rocks. Within the Roman Empire and limited to areas of warm/coastal climates such geologies can be found in the southern or western Iberian Peninsula, the Mediterranean coast of Algeria and Morocco, or western Turkey (Asch, 2005).

\section{Conclusions}

Strontium and oxygen isotope analysis for reconstructing geographic origin are relatively new techniques and applying them to the Roman period, where it is known that not only people but also foods moved over large distances, and in an area of significant geological diversity like Gloucestershire, is certainly ambitious. Our case-study has not only provided new evidence for diet and population composition at Roman Gloucester, but has also highlighted important issues regarding the reconstruction of migration in the past that need to be addressed by future research. It is clear that more work and human reference data are needed, not only from potential regions of origin, in this case the wider area of the Roman Empire, but also from (in comparison) already relatively well-studied places like Britain, in order to gauge the "normal" variation expected in stationary populations as well as to assess oxygen isotope variation through time due to climatic changes (see Daux et al., 2005). In order to achieve these things, future work will need to target not only sites where a large degree of population mobility is likely (such as a major Roman town and veteran settlement like Gloucester) but also nominally "less interesting" rural populations, where it may be expected that both humans and foodstuffs moved only within a relatively limited area. 
We have made a start at addressing these issues by surveying the available oxygen isotope evidence to derive a current best estimate for a human $\delta^{18} \mathrm{O}_{\mathrm{p}} \mathrm{UK}$-range (see appendix). Our suggested upper limit of $\sim 18.6 \%$ appears to be independently supported in the Gloucester data-set by the results of statistical analysis (kernel density estimations), and the carbon isotope evidence. Future work will show how robust this estimate is. The results suggest that six (28\%), possibly seven of the 21 individuals tested from Gloucester spent their childhoods in a warmer/more coastal climate than Roman Britain. Our results therefore demonstrate considerable diversity among the population of Roman Gloucester, even after the initial wave of incomers following the conquest of Britain.

\section{Acknowledgements}

This project was carried out as part of an AHRC "Diasporas, migrations and identities" research programme (AH/E58758). Samples and background information were kindly provided by Oxford Archaeology and we thank especially Drs. Louise Loe and Nicholas Márquez-Grant for their help. We thank Dr Mark Cave (British Geological Survey) for statistical advice and Dr Janet Montgomery (University of Bradford) for constructive comments.

\section{References}

Ambrose, S.H. 1993. Isotopic Analysis of Paleodiets: Methodological and Interpretive Considerations, in: Sandford, M.K. (Ed.), Investigations of Ancient Human Tissue: Chemical Analyses in Anthropology, Gordon \& Breach: Langthorne, pp. 59-130.

Asch, K., 2005. IGME 5000 Geological map of Europe and adjacent areas. BGR: Hanover.

Beard, B.L and Johnson, C.M. 2000. Strontium Isotope composition of skeletal material can determine the birth place and geographic mobility of humans and animal. Journal of Forensic Sciences, 45, 1049-1061.

Bentley, R.A., 2006. Strontium isotopes from the earth to the archaeological skeleton: a review. Journal of Archaeological Method and Theory 13: 135-187.

Bentley, R.A., Knipper, C., 2005. Geographical patterns in biologically available strontium, carbon and oxygen isotope signatures in prehistoric SW Germany. Archaeometry 47, 629-644.

Bentley, R.A., T.D. Price, E. Stephan, 2004. Determining the 'local' ${ }^{87} \mathrm{Sr} /{ }^{86} \mathrm{Sr}$ range for archaeological skeletons: a case study from Neolithic Europe. Journal of Archaeological Science 31, 365-375.

BGS Map, 2007. Bedrock Geology of the UK: South. British Geological Survey

Birck, J.L., 1986. Precision K-Rb-Sr isotopic analysis - application to $\mathrm{Rb}-\mathrm{Sr}$ chronology. Chemical Geology 56, 73-83.

Birley, A. 1979. The People of Roman Britain. Batsford, London. 
Bocherens, H., D. Drucker, 2003. Trophic Level Isotopic Enrichment of Carbon and Nitrogen in Bone Collagen: Case Studies from Recent and Ancient Terrestrial Ecosystems. International Journal of Osteoarchaeology 13, 46-53.

Britton, K., G. Müldner \& M. Bell. 2008. Stable isotope evidence for salt-marsh grazing in the Bronze Age Severn Estuary, UK: implications for palaeodietary analysis at coastal sites, Journal of Archaeological Science 35: 2111-2118.

Bryant, D.J., Froelich, P.N., Showers, W.J., Genna, B.J., 1996. Biologic and climatic signals in the oxygen isotope composition of Eocene-Ologocene liquid enamel phosphate. Palaeogeography, Palaeoclimatology, Palaeoecology 126, 75-89

Bryant, J.D., Luz, B., Froelich P.N., 1994. Oxygen isotopic composition of fossil horse tooth phosphate as a record of continental paleoclimate. Palaeogeography, Palaeoclimatology, Palaeoecology 107, 303-316.

Bryant, J.D., P.N. Froelich, 1995. A model of oxygen isotope fractionation in body water of large mammals. Geochimica et Cosmochimica Acta 59, 4523-4537.

Budd, P., J. Montgomery, B. Barreiro \& R.G. Thomas. 2000. Differential diagenesis of strontium in archaeological human dental tissues, Applied Geochemistry 15: 687-694.

Budd, P., Millard, A., Chenery, C., Lucy, S., Roberts, C., 2004. Investigating population movement by stable isotope analysis: a report from Britain. Antiquity 78, 127-141.

Cartwright, F.F., Biddiss, M.D., 2004. Disease and History. Sutton, Stroud.

Cool, H.E.M., 2006. Eating and Drinking in Roman Britain. Cambridge University Press, Cambridge.

Craig, O.E., M. Biazzo, T.C. O'Connell, P. Garnsey, C. Martinez-Labarga, R. Lelli, L. Salvadei, G. Tartaglia, A. Nava, L. Reno, A. Fiammenghi, O. Rickards \& L. Bondioli. 2009. Stable Isotopic Evidence for Diet at the Imperial Roman Coastal Site of Velia (1st and 2nd Centuries AD) in Southern Italy, American Journal of Physical Anthropology DOI 10.1002/ajpa.21021.

Crowson, R.A., Showers W.J., Wright E.K., Hoering, T.C., 1991. Preparation of phosphate samples for oxygen isotope analysis. Analytical Chemistry 63, 2397-2400.

Dark, P. 2000. The Environment of Britain in the First Millenium A.D., Duckworth, London

Darling, W. G. \& Talbot, J.C., 2003. The O \& H stable isotopic composition of fresh waters in the British Isles. 1. Rainfall. Hydrology And Earth System Sciences 7: 163-181.

Darling, W.C., Bath, A.H., Talbot, J.C., 2003. The O \& H stable isotopic composition of fresh waters in the British Isles: 2, Surface waters and groundwater. Hydrology and Earth System Sciences 7, 183-195.

Darling, W.G., 2004. Hydrological factors in the interpretation of stable isotopic proxy data present and past: a European perspective. Quaternary Science Reviews 23, 743-770.

Darling, W.G., Bath, A.H., Gibson, J.J., Rozanski, K., 2006. Isotopes in water in: Leng M.J. (Ed.), Isotopes in Palaeoenvironmental Research 10, Springer: London, pp. 1-52. 
Daux V, Lécuyer C., Héran M., Amiot R., Simon L., Fourel F., Martineau F., Lynnerup N., Reychler H., Escarguel G., 2008. Oxygen isotope fractionation between human phosphate and water revisited. Journal of Human Evolution doi:10.1016/j.jhevol.2008.06.006.

Daux, V, Lécuyer, C., Adam, F., Martineau, F., Vimeus, F., 2005. Oxygen isotope composition of human teeth and the record of climate changes in France (Lorraine) during the last 1700 years. Climatic Change 70, 445-464.

Daux, V., C. Lécuyer, F. Adam, F. Martineau \& F. Vimeux. 2005. Oxygen Isotope Composition of Human Teeth and the Record of Climate Changes in France (Lorraine) during the last 1700 Years, Climatic Change 70: 445-464.

DeNiro, M.J., 1985. Postmortem preservation and alteration of in vivo bone collagen isotope ratios in relation to palaeodietary reconstruction. Nature $317,806-809$.

Dobney, K., A. Hall, H. Kenward, 1999. It's all garbage. A review of bioarchaeology in the four English colonia towns In Hurst, H. (Ed.), The Coloniae of Roman Britain: New studies and a review. Portsmouth/Rhode Island, pp. 15-35.

Dufour E., Holmden C., Van Neer,, W., Zazzo A., Patterson, W.P., Degryse, P, Keppens, E., 2007. Oxygen and strontium isotopes as provenance indicators of fish at archaeological sites: the case study of Sagalassos, SW Turkey. Journal of Archaeological Science 34, 1226-1239.

Dupras, T.L. \& M.W. Tocheri. 2007. Reconstructing infant weaning histories at Roman period Kellis, Egypt using stable isotope analysis of dentition. American Journal of Physical Anthropology 134: 63-74.

Evans, J.A., Montgomery, J. and Wildman, G. 2009. Isotope domain mapping of $87 \mathrm{Sr} / 86 \mathrm{Sr}$ biosphere variation on the Isle of Skye, Scotland. Journal of the Geological Society $166,617-631$.

Evans, J., Chenery, C. A., Fitzpatrick, A.P., 2006b. Bronze Age childhood migration of individuals near Stonehenge, revealed by strontium and oxygen isotopes tooth enamel analysis. Archaeometry 48, 309-321.

Evans, J., Stoodley, N., Chenery, C., 2006a. A strontium and oxygen isotope assessment of a possible fourth century immigrant population in a Hampshire cemetery, southern England. Journal of Archaeological Science 33, 265-272.

Fiorato, V., Boylston, A., Knüsel, C., (Eds.), 2007. Blood Red Roses. The Archaeology of a Mass Grave from the Battle of Towton, AD 1461. 2nd revised ed. Oxbow Books, Oxford.

Fox D.L. and Fisher D.C., 2001. Stable isotope ecology of a late Miocene population of Gomphotherium productus (Mammalia, Proboscidea) from Port of Entry Pit, Oklahoma, USA. PALAIOS, V. 16, 279-293.

Fricke H.C., Clyde W.C., O'Neil, J.R., 1998. Intra-tooth variations in $\delta^{18} \mathrm{O}$ (PO4) of mammalian tooth enamel as a record of seasonal variations in continental climate variables. Geochimica et Cosmochemica Acta, 62 1839-1850. 
Fricke, H.C. \& J.R. O'Neil. 1999. The correlation between 18O/16O ratios of meteoric water and surface temperature: its use in investigating terrestrial climate change over geologic time, Earth and Planetary Science Letters 170: 181-196.

Fulford, M., 1999. Veteran settlement in 1st-c. Britain and the foundations of Gloucester and Lincoln in: Hurst, H. (Ed.), The Coloniae of Roman Britain: New Studies and A Review. Journal of Roman Archaeology Supplementary Series 36, Portsmouth, Rhode Island, pp. 177-180.

Fuller, B.T., Molleson, T.I., Harris, D.A., Gilmour, L.T., Hedges, R.E.M., 2006. Isotopic evidence for breastfeeding and possible adult dietary differences from late/sub-Roman Britain. American Journal of Physical Anthropology 129, 45-54.

Gilliam, J.F., 1961. The plague under Marcus Aurelius. American Journal of Philology 82, 225-251.

Grainger, I., Hawkins, D., Cowal, L., Mikulski, R. 2008. The Black Death Cemetery, East Smithfield, London. MoLAS Monograph 43, Museum of London Archaeology Service: London.

Greenburg, J., 2003. Plagued by doubt: reconsidering the impact of the mortality crisis in the 2nd c. AD. Journal of Roman Archaeology 16, 413-425

Hassall, M., Hurst, H., 1999. Soldier and civilian: a debate on the bank of the Severn in: Hurst, H. (Ed.), The Coloniae of Roman Britain: New Studies and A Review. Journal of Roman Archaeology Supplementary Series 36, Portsmouth, Rhode Island, pp. 181189.

Hedges, R.E.M., J.G. Clement, C.D.L. Thomas \& T.C. O'Connell. 2007. Collagen Turnover in the Adult Femoral Mid-Shaft: Modeled from Anthropogenic Radiocarbon Tracer Measurements, American Journal of Physical Anthropology 133: 808-816.

Hillson, S., 1996. Dental Anthropology. Cambridge University Press, Cambridge

Hoppe, K.A., Koch, P.L., Furutani, T.T., 2003. Assessing the preservation of biogenic strontium in fossil bones and tooth enamel. International Journal of Osteoarchaeology $13,20-28$.

Hurst, H., 1999. Topography and identity in Glevum colonia in: Hurst, H. (Ed.), The Coloniae of Roman Britain: New Studies and A Review. Journal of Roman Archaeology Supplementary Series 36, Portsmouth, Rhode Island, pp. 113-135.

Hurst, H., 2005. Roman Cirencester and Gloucester compared. Oxford Journal of Archaeology 24, 293-305.

Hurst, H.R. 1985. Kingsholm. Gloucester Archaeological Publications, Gloucester.

Iacumin, P., Bocherens, H., Mariotti, A., Longinelli, A. 1996. An isotopic palaeoenvironmental study of human skeletal remains from the Nile Valley. Palaeogeography, Palaeoclimatology, Palaeoecology 126: 15-30.

IAEA/WISER. 2008. Water Isotope System for Data Analysis and Electronic Retrieval. IAEA Water Resources Programme. http://nds121.iaea.org/wiser/ 
Jackson, R., 1988. Doctors and diseases in the Roman Empire. British Museum Publications, London.

Jim, S., V. Jones, S.H. Ambrose \& R.P. Evershed. 2006. Quantifying dietary macronutrient sources of carbon for bone collagen synthesis using natural abundance stable carbon isotope analysis, British Journal Of Nutrition 95: 1055-1062.

Keenleyside, A., H. Schwarcz, L. Stirling, N. Ben Lazreg. 2009. Stable isotopic evidence for diet in a Roman and Late Roman population from Leptiminus, Tunisia. Journal of Archaeological Science 36: 51-63

Kohn, M.J., 1996. Predicting animal $\delta^{18} \mathrm{O}$ : Accounting for diet and physiological adaptation. Geochimica et Cosmochimica Acta 60, 4811-4829.

Kolodny, Y., Luz, B., Navon, O., 1983. Oxygen isotope variations in phosphate of biogenic apatites, I: Fish bone apatite - rechecking the rules of the game. Earth and Planetary Science Letters 64, 398-404.

Lecolle, P., 1985. The oxygen isotope composition of landsnail shells as a climatic indicator applications to hydrogeology and paleoclimatology. Chemical Geology 58, 157-181.

Lécuyer, C., Bogey, C., Garcia, J. P, Grandjean, P., Barrat, J.A., Floquet, M., Bardet, N., Pereda-Superbiola, X., 2003. Stable isotope composition and rare earth element content of vertebrate remains from the Late Cretaceous of northern Spain (Lano): did the environmental record survive? Palaeogeography, Palaeoclimatology, Palaeoecology 193, 457-471.

Lécuyer, C., Fourel, F., Martineau, F., Amiot, R., Bernard, A., Daux, V., Escarguel, G., Morrison, J., 2007. High-precision determination of 18O/16O ratios of silver phosphate by EA-pyrolysis-IRMS continuous flow technique. Journal of. Mass Spectrometry 42: 36-41.

Lécuyer, C., Grandjean, P., Emig, C.C., 1996. Determination of oxygen isotope fractionation between water and phosphate from living lingulids: potential application to palaeoenvironmental studies. Palaeogeography, Palaeoclimatology, Palaeoecology $126,101-108$.

Levinson, A.A., Luz, B., and Kolodny, Y., 1987. Variations in oxygen isotope compositions of human teeth and urinary stones. Applied Geochemistry 2, 367-71.

Littman, R.J., Littman, M.L., 1973. Galen and the Antonine plague. American Journal of Philology 94, 243-255.

Longin, R., 1971. New method of collagen extraction for radiocarbon dating. Nature 230, 241-242.

Longinelli, A., 1965. Oxygen isotopic composition of orthophosphate from shells of living marine organisms. Nature 207, 716-719.

Longinelli, A., 1984, Oxygen isotopes in mammal bone phosphate: a new tool for palaeohydrological and palaeoclimatological research? Geochimica et Cosmochimica Acta 48, 385-390. 
Longinelli, A., Selmo, E., 2003. Isotopic composition of precipitation in Italy: a first overall map. Journal of Hydrology 270, 75-88.

Luz, B., Kolodny, Y., Horowitz, M., 1984. Fractionation of oxygen isotopes between mammalian bone-phosphate and environmental drinking water. Geochimica et Cosmochimica Acta 48, 1689-1693.

Luz, B., Y. Kolodny, 1985. Oxygen isotope variations in phosphate of biogenic apatites, IV. Mammal teeth and bones. Earth and Planetary Science Letters 75, 29-36.

Lykoudis, S.P., Argiriou, A.A., 2007. Gridded data set of the stable isotopic composition of precipitation over the eastern and central Mediterranean. Journal of Geophysical Research 112, D18107, doi:10.1029/2007JD008472.

Mann, J., 1983. Legionary recruitment and veteran settlement during the principate. Institute of Archaeology Occasional Paper 7, University of London, London.

Márquez-Grant, N. Loe, L., 2008. The human remains in: Simmonds, A., Márquez-Grant, N., Loe, L., (Eds.), Life and Death in a Roman City: Excavation of a Roman Cemetery with a Mass Grave at 120-122 London Road, Gloucester. Oxford Archaeology Monograph No. 6. Oxford Archaeology Unit, Oxford, pp. 29-80.

McNeill, W.H., 1977. Plagues and Peoples. Peregrine Books: Oxford

McWhirr, A., 1981. Roman Gloucestershire. Alan Sutton, Gloucester.

Millett, M., 1999. Coloniae and Romano-British studies in: Hurst, H. (Ed.), The Coloniae of Roman Britain: New Studies and A Review. Journal of Roman Archaeology Supplementary Series 36, Portsmouth, Rhode Island, pp. 191-196

Montgomery J., Evans, J.A., Wildman G., 2006. ${ }^{87} \mathrm{Sr} /{ }^{86} \mathrm{Sr}$ isotope composition of bottled British mineral waters for environmental and forensic purposes. Applied Geochemistry 21, 1626-1634.

Montgomery, J., 2002. Lead and Strontium Isotope Compositions of Human Dental Tissues as an Indicator of Ancient Exposure and Population Dynamics, Unpublished $\mathrm{PhD}$ Thesis, Bradford University, Bradford.

Montgomery, J., Evans, J., Cooper, R.E. 2007. Resolving archaeological populations with Srisotope mixing models. Applied Geochemistry 22: 1502-1514.

Müldner, G., Richards, M.P., 2007. Stable isotope evidence for 1500 years of human diet at the City of York, UK. American Journal of Physical Anthropology 133, 682-697.

Müller, W., Fricke, H., Halliday, A.N., McCulloch, M.T.,Wartho, J.A., 2003. Origin and migration of the Alpine Iceman. Science 302, 862-866.

O'Neil, J.R., Roe, L.J., Reinhard, E., Blake, R.E., 1994. A rapid and precise method of oxygen isotope analysis of biogenic phosphate. Israel Journal of Earth Science 43, 203-212.

Perry, M.A., D. Coleman, N. Delhopital, 2008. Mobility and Exile at $2^{\text {nd }}$ Century A.D. Khirbet edh-Dharih: Strontium Isotope Analysis of Human Migration in Western Jordan. Geoarchaeology 23, 528-549. 
Price, T.D., Burton, J.H., Bentley, R.A., 2002. The characterization of biologically available strontium isotope ratios for the study of prehistoric migration. Archaeometry 44, 117 135.

Prowse, T., Schwarcz, H.P., Saunders, S., Macchiarelli, R., Bondioli, L., 2004. Isotopic paleodiet studies of skeletons from the Imperial Roman-age cemetery of Isola Sacra, Rome, Italy. Journal of Archaeological Science 31, 259-272.

Prowse, T.L., H.P. Schwarcz, P. Garnsey, M. Knyf, R. Macchiarelli, L. Bondioli, 2007. Isotopic Evidence for Age-Related Immigration to Imperial Rome. American Journal of Physical Anthropology 132, 510-519.

Prowse, T.L., Schwarcz, H.P., Saunders, S.R., Macchiarelli, R., Bondioli, L., 2005. Isotopic evidence for age-related variation in diet from Isola Sacra, Italy. American Journal of Physical Anthropology 132, 510-519.

Reece, R., 1999. Colonia in context: Glevum and the civitas Dobunnorum in: Hurst, H. (Ed.), The Coloniae of Roman Britain: New Studies and A Review. Journal of Roman Archaeology Supplementary Series 36, Portsmouth, Rhode Island, pp. 73-85.

Richards, M.P., Hedges, R.E.M., Molleson, T.I., Vogel, J.C., 1998. Stable isotope analysis reveals variations in human diet at the Poundbury Camp cemetery site. Journal of Archaeological Science 25, 1247-1252.

RSC, 2006: Royal Society of Chemistry, 2006, AMC Technical Brief 4, Representing data distributions with kernel density estimates. www.rsc.org/amc/

Schwarcz, H.P. \& M.J. Schoeninger. 1991. Stable Isotope Analyses in Human Nutritional Ecology, Yearbook of Physical Anthropology 34: 283-321.

Schweissing, M.M., G. Grupe, 2003. Stable strontium isotopes in human teeth and bone: a key to migration events of the late Roman period in Bavaria. Journal of Archaeological Science 30, 1373-1383.

Sealy, J., 2001. Body tissue chemistry and Palaeodiet in: Brothwell, D.R., Pollard, A. M., (Eds.), Handbook of Archaeological Science. John Wiley \& Sons, Chichester, pp. 269-279.

Sealy, J., Armstrong, R., Schrire, C., 1995. Beyond lifetime averages - tracing life-histories through isotopic analysis of different calcified tissues from archaeological human skeletons. Antiquity 69, 290-300.

Sharma, S., Joachimski, M.M., Tobschall, H.J., Singh, I.B., Tewari, D.P., Tewari, R., 2004. Oxygen isotopes of bovid teeth as archives of paleoclimatic variations in archaeological deposits of the Ganga plain, India. Quaternary Research 62, 19- 28.

Shemesh, A., Kolodny, Y., Luz, B., 1983. Oxygen isotope variations in phosphate of biogenic apatites, II Phosphorite rocks. Earth and Planetary Science Letters 64, 405-416.

Shemesh, A., Kolodny, Y., Luz, B., 1988. Isotope geochemistry of oxygen and carbon in phosphate and carbonate of phosphorite francolite. Geochimica et Cosmochimica Acta $52,2565-2572$. 
Shoesmith, R., Stone, P., 1995. Burials at Hereford Cathedral. Current Archaeology 142, 400405.

Sillen, A., G. Hall, S. Richardson \& R. Armstrong. 1998. Sr-87/Sr-86 ratios in modern and fossil food-webs of the Sterkfontein Valley: Implications for early hominid habitat preference, Geochimica et Cosmochimica Acta 62: 2463-2473.

Simmonds, A., Márquez-Grant, N., Loe, L., 2008. Life and Death in a Roman City: Excavation of a Roman Cemetery with a Mass Grave at 120-122 London Road, Gloucester. Oxford Archaeology Monograph 6, Oxford Archaeological Unit, Oxford.

Smith, B.H. 1991. Standards of human tooth formation and dental age assessment, in: Kelley, M.A. \& C.S. Larsen (Eds.), Advances in Dental Anthropology, Wiley-Liss: New York, pp. 143-168.

Spiro, B., Darbyshire, D., Smith, B., Ferguson, A.J., Antich, N., Nunez, R., 2001. Isotope study of the origin and distribution of sulphate in waters from the Worcester Basin, UK in: Cidu, R. (Ed.), Proceedings of 10th Symposium Water-Rock Interaction, Villasimius, Italy, Balkema, Lisse, pp. 1147-1150.

Stephan, E., 2000. Oxygen isotope analysis of animal bone phosphate: method refinement, influence of consolidants, and reconstruction of palaeo temperatures for Holocene sites. Journal of Archaeological Science 25, 523-535

Swindles, G.T., A. Blundell, H.M. Roe \& V.A. Hall. 2009. A 4500-year proxy climate record from peatlands in the North of Ireland: the identification of widespread summer 'drought phases'?, Quaternary Science Reviews doi: 10.1016/j.quascirev.2009.01.003.

Toolis, R. (submitted). Excavation of medieval graves at St Thomas' Kirk, Hall of Rendall, Orkney. Proceedings of the Society of Antiquities of Scotland

Toynbee, J.M.C. 1971. Death and Burial in the Roman World. Thames \& Hudson, London

Trickett, M A, 2008 A Tale of Two Cities: Diet, Health and Migration in Post-Medieval Coventry and Chelsea through Biographical Reconstruction, Osteoarchaeology and Isotope Biogeochemistry. Unpublished PhD Thesis, Durham University.

Tütken, T., Vennemann, T.W., Janz, H., Heizmann, E.P., 2006. Palaeoenvironment and palaeoclimate of the Middle Miocene Lake in the Steinheim basin, SW Germany: A reconstruction from $\mathrm{C}, \mathrm{O}$, and $\mathrm{Sr}$ isotopes of fossil remains. Palaeogeography, Palaeoclimatology, Palaeoecology 241, 457-491.

van Klinken, G.J., 1999. Bone collagen quality indicators for palaeodietary and radiocarbon measurements. Journal of Archaeological Science 26, 687-695.

van Klinken, G.J., Richards, M.P., Hedges, R.E.M., 2000. An overview of causes for stable isotopic variations in past European human populations: environmental, ecophysiological, and cultural effects in: Ambrose, S.H., Katzenberg, M.A., (Eds.), Biogeochemical Approaches to Palaeodietary Analysis. Kluwer Academic/Plenum, New York, pp. 39-63. 
Vennemann, T.W., Fricke H.C., Blake, R.E., O'Neil, J.R., Colman, A., 2002. Oxygen isotope analysis of phosphates: a comparison of techniques for analysis of Ag3PO4. Chemical Geology 185, 321-336.

Wacher, J. 1974. The Towns of Roman Britain. Batsford, London.

Wahl, J. König, H.G. 1987. Anthropologisch-traumatologische Untersuchung der menschlichen Skelettreste aus dem bandkeramischen Massengrab bei Talheim, Kreis Heilbronn. Fundberichte aus Baden-Würtemberg 12, 65-193.

White, C., Longstaffe, F.J., Law, K.R., 2004. Exploring the effects of environment, physiology and diet on oxygen isotope ratios in ancient Nubian bones and teeth. Journal of Archaeological Science 31: 233-250.

White, C.D., Spence, M.W., Stuart-Williams, H.L., Schwarcz, H.P., 1998. Oxygen Isotopes and the Identification of Geographical Origins: The Valley of Oaxaca versus the Valley of Mexico. Journal or Archaeological Science 25: 643-655.

Wild, E.M., Arlamovsky, K.A., Golser, R., Kutschera, W., Priller, A., Puchegger, S., Rom, W., Steier, P., Vycudilik, W., 2000. 14C dating with the bomb peak: An application to forensic medicine. Nuclear Instruments and Methods in Physics Research B: Beam Interactions with Materials \& Atoms 172, 944-950.

Wright, L. E., Schwarcz, H.P., 1998. Stable carbon and oxygen isotopes in human tooth enamel: Identifying breastfeeding and weaning in prehistory. American Journal of Physical Anthropology 106, 1-18.

Zazzo, A., Lecuyer, C., Sheppard, S.M.F., Grandjean, P., Mariotti, A., 2004. Diagenesis and the reconstruction of paleoenvironments: A method to restore original delta O-18 values of carbonate and phosphate from fossil tooth enamel. Geochimica et Cosmochimica Acta 68, 2245-2258. 


\section{Tables \& Figures}

\section{Main Text}

Table 1. Carbon and nitrogen stable isotope data and collagen quality indicators (see van Klinken 1999) for dentine samples and strontium isotope data and elemental concentrations as well as oxygen stable isotope data from enamel phosphate $\left(\delta^{18} \mathrm{O}_{\mathrm{p}}\right)$ and converted drinking water values using the equation by $\mathrm{xx}\left(\delta^{18} \mathrm{O}_{\mathrm{dw}}\right)$ with basic archaeological and anthropological information for the sampled individuals.

\begin{tabular}{|c|c|c|c|c|c|c|c|c|c|c|c|c|c|c|c|}
\hline Sample & Tooth & $\delta^{13} \mathrm{C}$ & $\delta^{51} \mathrm{~N}$ & $\% \mathrm{C}$ & $\% \mathrm{~N}$ & $\mathrm{C} / \mathrm{N}$ & $\%$ coll. & ${ }^{87} \mathrm{Sr} /{ }^{86} \mathrm{Sr}$ & $\mathrm{Sr} / \mathrm{ppm}$ & $\delta^{81} \mathrm{O}_{\mathrm{p}}$ & $\pm 2 \sigma$ & $\delta^{81} \mathrm{O}_{\mathrm{dw}}$ & $\pm 2 \sigma$ & Sex & Age \\
\hline \multicolumn{16}{|c|}{ Discrete Burials } \\
\hline GLR1103 & M3 & -20.1 & 12.2 & 42.8 & 15.4 & 3.2 & 11.6 & 0.70944 & 114 & 18.4 & 0.3 & -5.1 & 0.5 & $\mathrm{~F}$ & YMA \\
\hline GLR1127 & M3 & -20.0 & 10.4 & 42.6 & 15.2 & 3.3 & 5.1 & 0.70967 & 121 & 17.2 & 0.3 & -7.8 & 0.6 & $? \mathrm{M}$ & YA \\
\hline GLR1131 & M3 & -19.3 & 12.6 & 43.0 & 15.4 & 3.3 & 12.2 & 0.71143 & 133 & 17.1 & 0.3 & -8.1 & 0.6 & $\mathrm{~F}$ & YA \\
\hline GLR1181 & M2 & -20.1 & 10.8 & 41.3 & 14.9 & 3.2 & 10.2 & 0.71057 & 76 & 17.6 & 0.3 & -6.9 & 0.7 & $\mathrm{~F}$ & YMA \\
\hline GLR1216 & M3 & -19.2 & 10.9 & 41.9 & 15.1 & 3.2 & 7.1 & 0.70941 & 93 & 19.2 & 0.3 & -3.5 & 0.7 & M & OMA \\
\hline GLR1216 & Dentine & -- & -- & -- & -- & -- & -- & 0.70931 & 98 & -- & -- & -- & -- & & \\
\hline GLR1238 & M3 & -20.3 & 10.7 & 43 & 14.9 & 3.4 & 6.7 & 0.70891 & 52 & 17.1 & 0.1 & -7.9 & 0.2 & $? \mathrm{M}$ & OMA \\
\hline GLR1328 & M3 & -19.5 & 12.0 & 42.5 & 15.3 & 3.2 & 6.6 & 0.71056 & 57 & 18.0 & 0.3 & -6.1 & 0.6 & M & YMA \\
\hline GLR1340 & M2 & -20.1 & 10.3 & 41.6 & 15.0 & 3.2 & 6.4 & 0.70958 & 104 & 17.9 & 0.3 & -6.3 & 0.7 & ND & $\mathrm{OA}$ \\
\hline GLR1360 & M2 & -19.2 & 9.9 & 43.1 & 15.7 & 3.2 & 11.8 & 0.70900 & 133 & 19.0 & 0.4 & -3.9 & 0.8 & $\mathrm{~F}$ & YA \\
\hline GLR1364 & M3 & -20.3 & 12.0 & 42.5 & 15.3 & 3.2 & 8.4 & 0.71138 & 104 & 18.2 & 0.2 & -5.6 & 0.4 & ?F & YA \\
\hline \multicolumn{16}{|c|}{ Mass Burial } \\
\hline GLR1518 & M2 & -20.1 & 10.2 & 42.5 & 15.5 & 3.2 & 6.8 & 0.71298 & 72 & 17.9 & 0.3 & -6.3 & 0.7 & M? & YMA \\
\hline GLR1520 & M3 & -19.5 & 12.2 & 42.4 & 15.3 & 3.2 & 7.3 & 0.70971 & 130 & 18.6 & 0.1 & -4.7 & 0.3 & $\mathrm{~F}$ & YA \\
\hline GLR1539 & M3 & -20.3 & 10.7 & 42.9 & 15.4 & 3.3 & 6.4 & 0.70878 & 66 & 17.5 & 0.1 & -7.2 & 0.2 & $\mathrm{~F}$ & YMA \\
\hline GLR1541 & M3 & -20.3 & 8.8 & 42.3 & 15.2 & 3.2 & 5.1 & 0.71217 & 51 & 17.1 & 0.2 & -8.1 & 0.4 & M & YA \\
\hline GLR1544 & M3 & -20.3 & 11.9 & 42.6 & 15.3 & 3.3 & 7.1 & 0.70994 & 102 & 18.2 & 0.2 & -5.7 & 0.4 & M & YMA \\
\hline GLR1546 & M3 & -18.8 & 11.9 & 42.1 & 15.1 & 3.3 & 5.0 & 0.71086 & 177 & 19.1 & 0.1 & -3.8 & 0.3 & ND & OMA \\
\hline GLR1553 & M3 & -20.1 & 12.6 & 42.6 & 15.5 & 3.2 & 7.6 & 0.70924 & 84 & 17.4 & 0.4 & -7.3 & 0.9 & M & YMA \\
\hline GLR1560 & M3 & -18.9 & 12.3 & 42.4 & 15.4 & 3.2 & 6.2 & 0.70946 & 114 & 18.7 & 0.4 & -4.5 & 0.9 & $\mathrm{~F}$ & YA \\
\hline GLR1560 & Dentine & -- & -- & -- & -- & -- & -- & 0.70921 & 349 & -- & -- & -- & -- & & \\
\hline GLR1561 & M3 & -- & -- & -- & -- & -- & -- & 0.71344 & 67 & 18.7 & 0.2 & -4.5 & 0.5 & M & YA \\
\hline GLR1565 & M2 & -19.0 & 11.7 & 42.8 & 15.5 & 3.2 & 6.7 & 0.70975 & 104 & 19.0 & 0.3 & -3.9 & 0.6 & $\mathrm{~F}$ & YA \\
\hline GLR1596 & M2 & -19.7 & 11.3 & 42.8 & 15.7 & 3.2 & 10.1 & 0.70904 & 105 & 17.7 & 0.3 & -6.7 & 0.6 & F & YMA \\
\hline
\end{tabular}

Key: cem= cemetery burial; $\mathrm{mb}=$ mass-burial pit; $\mathrm{F}=$ female, ?F = probably female; $\mathrm{M}=$ male; ?M = probably male; ND = not determined; $\mathrm{A}=$ adult $($ age-at-death c. 18 - >45 years); YA = Young Adult (c. 18-25 years); YMA = Young Middle Adult (c. 26-35 years); OMA = Old Middle Adult (c. 36-45 years); OA = Old Adult (>c.45 years). 
Table 2. Location, vegetation type, geology and ${ }^{87} \mathrm{Sr} /{ }^{86} \mathrm{Sr}$ values for bio-accessible $\mathrm{Sr}$ from vegetation

\begin{tabular}{|c|c|c|c|c|c|c|c|}
\hline Geologic Era/Period & Sample & Latitude & Longitude & Vegetation Type & $\begin{array}{l}\text { Superficial } \\
\text { deposits }\end{array}$ & Bedrock Geology & $\begin{array}{l}{ }^{87} \mathrm{Sr} /{ }^{86} \mathrm{Sr} \\
\text { Ratio }\end{array}$ \\
\hline \multicolumn{8}{|l|}{ PROTEROZOIC } \\
\hline \multicolumn{8}{|l|}{ Precambrian } \\
\hline & G-V-026 & 52.03020 & -2.35129 & Herbs & & Hornblend Gneiss & 0.71622 \\
\hline \multicolumn{8}{|l|}{ PALAEOZOIC } \\
\hline \multicolumn{8}{|l|}{ Lower Cambrian } \\
\hline & G-V-025 & 52.03065 & -2.35332 & Herbs & & Sandstone & 0.71038 \\
\hline & G-V-027 & 52.03129 & -2.35517 & Grass \& Herbs & & Sandstone & 0.71202 \\
\hline & G-V-028 & 52.02890 & -2.35497 & Grass \& Herbs & & Sandstone & 0.71352 \\
\hline & G-V-029 & 52.02779 & -2.35856 & Bramble & $\operatorname{Head}^{1}$ & Sandstone & 0.71201 \\
\hline \multicolumn{8}{|l|}{ Lower Ordovician } \\
\hline & G-V-030 & 52.02739 & -2.36220 & Herbs & Head & Mudstone & 0.71508 \\
\hline \multicolumn{8}{|l|}{ Lower Silurian } \\
\hline & G-V-031 & 52.02799 & -2.37398 & Grass & $\operatorname{Head}^{1}$ & Sandstone & 0.71292 \\
\hline & G-V-032 & 52.04640 & -2.40285 & Grass & & Siltstone + Mudstone & 0.71010 \\
\hline & G-V-033 & 52.02395 & -2.43141 & Grass & & Siltstone + Mudstone & 0.71206 \\
\hline \multicolumn{8}{|l|}{ Early Devonian } \\
\hline & G-V-015 & 51.82224 & -2.46547 & Grass \& Herbs & & Sandstone + Mudstone & 0.71133 \\
\hline & G-V-016 & 51.81370 & -2.47524 & Grass \& Herbs & & Sandstone + Mudstone & 0.71293 \\
\hline \multicolumn{8}{|l|}{ Upper Carboniferous } \\
\hline & G-V-017 & 51.83878 & -2.54159 & Herbs & & Sandstone & 0.71285 \\
\hline & G-V-018 & 51.80259 & -2.62067 & Grass \& Herbs & & Sandstone & 0.71185 \\
\hline MESOZOIC & & & & & - & & \\
\hline Early Permian & G-V-034 & 51.99873 & -2.38201 & Grass \& Herbs & - & Sandstone & 0.71060 \\
\hline \multicolumn{8}{|l|}{ Late Triassic } \\
\hline & G-V-023 & 52.00281 & -2.22317 & Grass & Head $^{1}$ & Mudstone & 0.71546 \\
\hline & G-V-024 & 52.02729 & -2.32340 & Grass & Head $^{1}$ & Mudstone & 0.71418 \\
\hline & G-V-035 & 51.98775 & -2.36629 & Grass & & Sandstone & 0.71163 \\
\hline & G-V-013 & 51.86250 & -2.35389 & Grass \& Herbs & $\begin{array}{l}\text { Tidal flat } \\
\text { deposits }\end{array}$ & Mudstone & 0.70979 \\
\hline \multicolumn{8}{|l|}{ Early Jurassic } \\
\hline & G-V-009 & 51.76471 & -2.21472 & Grass \& Herbs & Landslip & Limestone + Mudstone & 0.70982 \\
\hline & G-V-010 & 51.79165 & -2.22313 & Grass \& Herbs & Landslip & Limestone + Mudstone & 0.70901 \\
\hline & G-V-021 & 51.92102 & -2.14143 & Grass \& Herbs & Alluvium & Mudstone & 0.70936 \\
\hline & G-V-022 & 51.90726 & -2.14167 & Grass \& Herbs & & Mudstone & 0.70923 \\
\hline & G-V-001 & 51.85597 & -2.13270 & Herbs & $\begin{array}{l}\text { River Terrace } \\
\text { Deposits }\end{array}$ & Mudstone & 0.70925 \\
\hline
\end{tabular}




\begin{tabular}{|c|c|c|c|c|c|c|}
\hline & & & & River Terrace & & \\
\hline G-V-002 & 51.85981 & -2.12531 & Grass \& Herbs & Deposits & Mudstone & 0.70916 \\
\hline G-V-011 & 51.80265 & -2.24166 & Grass \& Herbs & & Mudstone & 0.71099 \\
\hline G-V-012 & 51.86084 & -2.25038 & Grass \& Herbs & $\begin{array}{l}\text { Tidal flat } \\
\text { deposits }\end{array}$ & Mudstone & 0.70952 \\
\hline G-V-014 & 51.79634 & -2.37385 & Grass \& Herbs & deposits & Mudstone & 0.70934 \\
\hline G-V-020 & 51.90494 & -2.15949 & Grass \& Herbs & & Mudstone + Limestone & 0.70902 \\
\hline G-V-006 & 51.78573 & -2.05608 & Herbs \& Grass & & Limestone & 0.70817 \\
\hline G-V-008 & 51.76160 & -2.15329 & Grass \& Herbs & & Sandstone & 0.71132 \\
\hline G-V-003 & 51.84497 & -2.07768 & Herbs & & Oolitic Limestone & 0.70792 \\
\hline G-V-004 & 51.83532 & -2.10376 & Grass \& Herbs & Landslip & Oolitic Limestone & 0.70800 \\
\hline G-V-005 & 51.81699 & -2.08156 & Herbs \& Grass & & Oolitic Limestone & 0.70767 \\
\hline G-V-007 & 51.78592 & -2.11550 & Grass \& Herbs & & Oolitic Limestone & 0.70832 \\
\hline
\end{tabular}

( 1 glacial head deposits in the vicinity, but not dominating the sampling area.).

Table 3. Carbon and nitrogen stable isotope data and bone collagen quality indicators for London Road faunal remains.

\begin{tabular}{lllllllll}
\hline Sample & Species & $\boldsymbol{\delta}^{\mathbf{1 3}} \mathbf{C}$ & $\boldsymbol{\delta}^{\mathbf{1 5}} \mathbf{N}$ & $\mathbf{\%} \mathbf{C}$ & $\boldsymbol{\%} \mathbf{N}$ & $\mathbf{C} / \mathbf{N}$ & $\boldsymbol{\%}$ Coll & Context \\
\hline GLR-F-1 & cattle & -22 & 6.6 & 30.7 & 11 & 3.3 & 7.7 & 1044 \\
GLR-F-2 & cattle & -21.7 & 6.2 & 41.5 & 14.8 & 3.3 & 3.5 & 1106 \\
GLR-F-3 & cattle & -21.7 & 7.1 & 38.4 & 13.8 & 3.2 & 4.5 & 1212 \\
GLR-F-4 & cattle & -21.2 & 6.6 & 30.3 & 10.9 & 3.3 & 4.2 & 1300 \\
GLR-F-10 & sheep/goat & -21.4 & 5.4 & 42.3 & 15 & 3.3 & 2.9 & 1106 \\
GLR-F-5 & domestic fowl & -20.7 & 8.8 & 30 & 10.5 & 3.3 & 5.2 & 1171 \\
GLR-F-6 & horse & -22.3 & 7.2 & 27.5 & 10 & 3.2 & 5 & 1106 \\
GLR-F-7 & horse & -21.7 & 4.7 & 34.7 & 12.2 & 3.3 & 5.9 & 1318 \\
GLR-F-8 & pig & -21.4 & 5.5 & 20.8 & 7.2 & 3.4 & 1.2 & 1142 \\
\hline
\end{tabular}




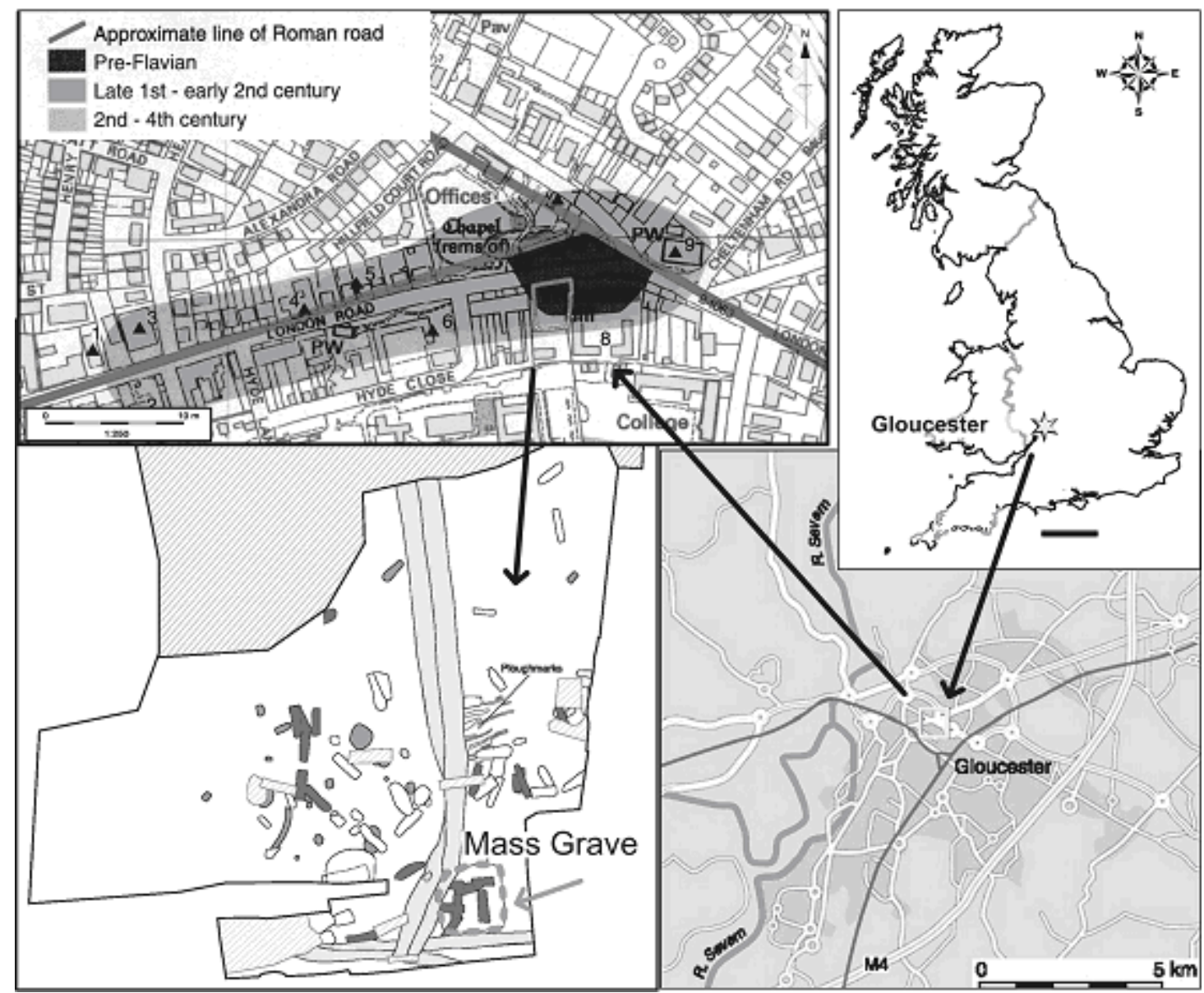

Figure 1

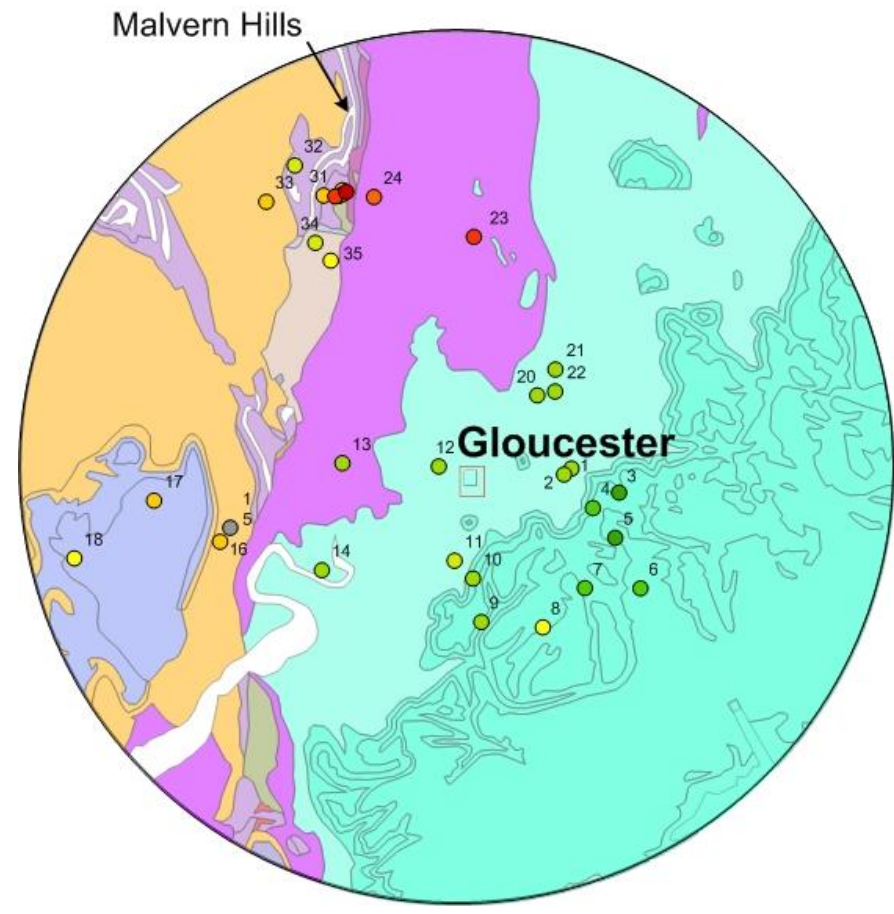

Vegitation

${ }^{87} \mathrm{Sr}^{86}$ SR_Ratio

- $0.000-0.707$

- $0.707-0.708$

- $0.708-0.709$

- $0.709-0.710$

○ $0.710-0.711$

○ $0.711-0.712$

- $0.712-0.713$

○ $0.713-0.714$

- $0.714-0.715$

- $0.715-0.716$

- $0.716-0.717$

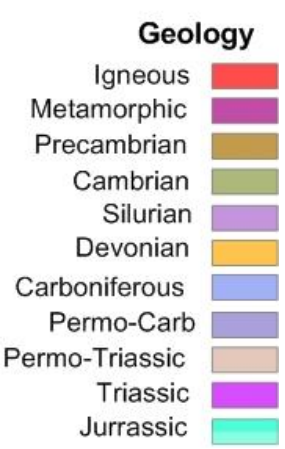

Figure 2. 


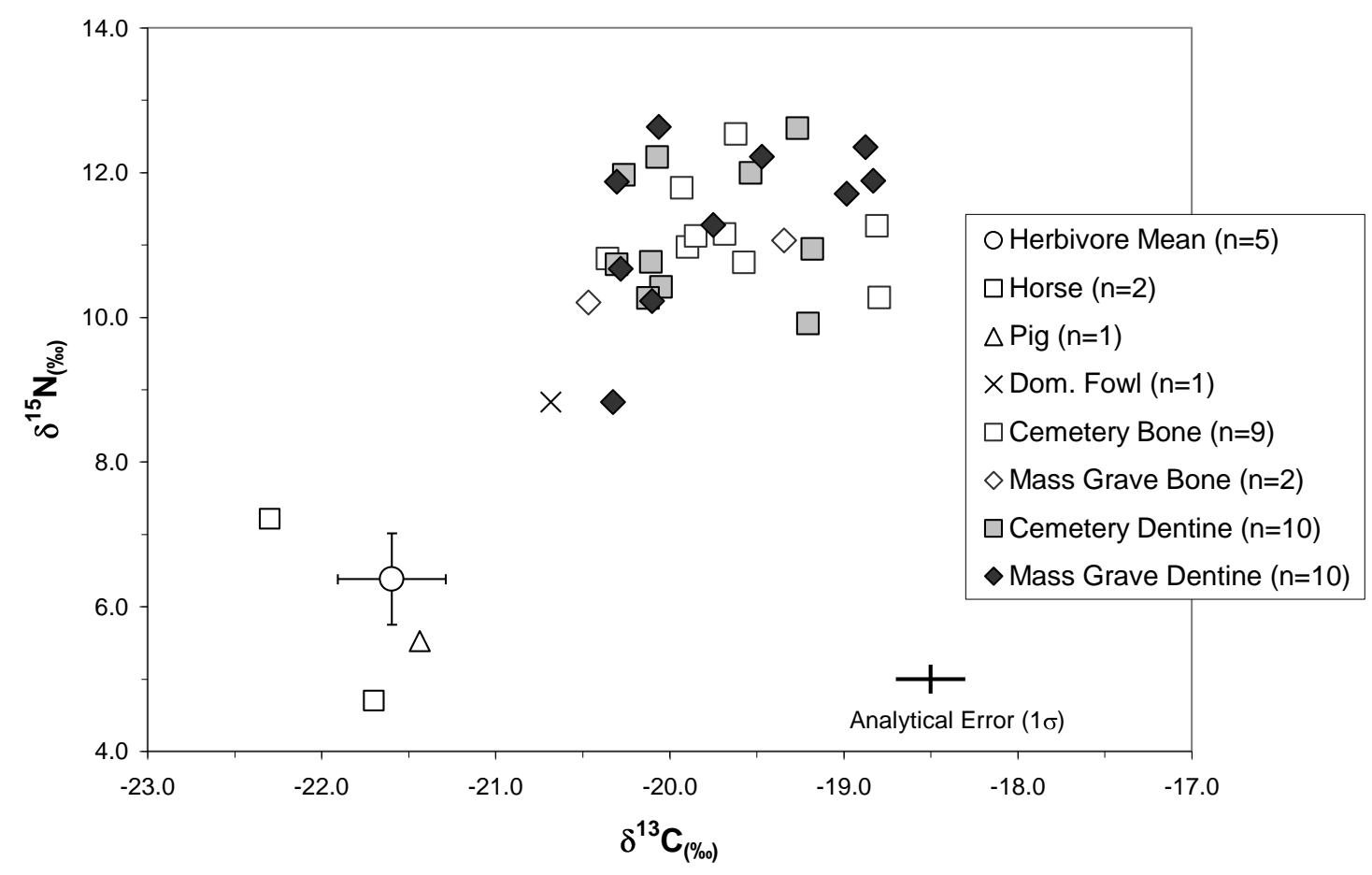

Figure 3.

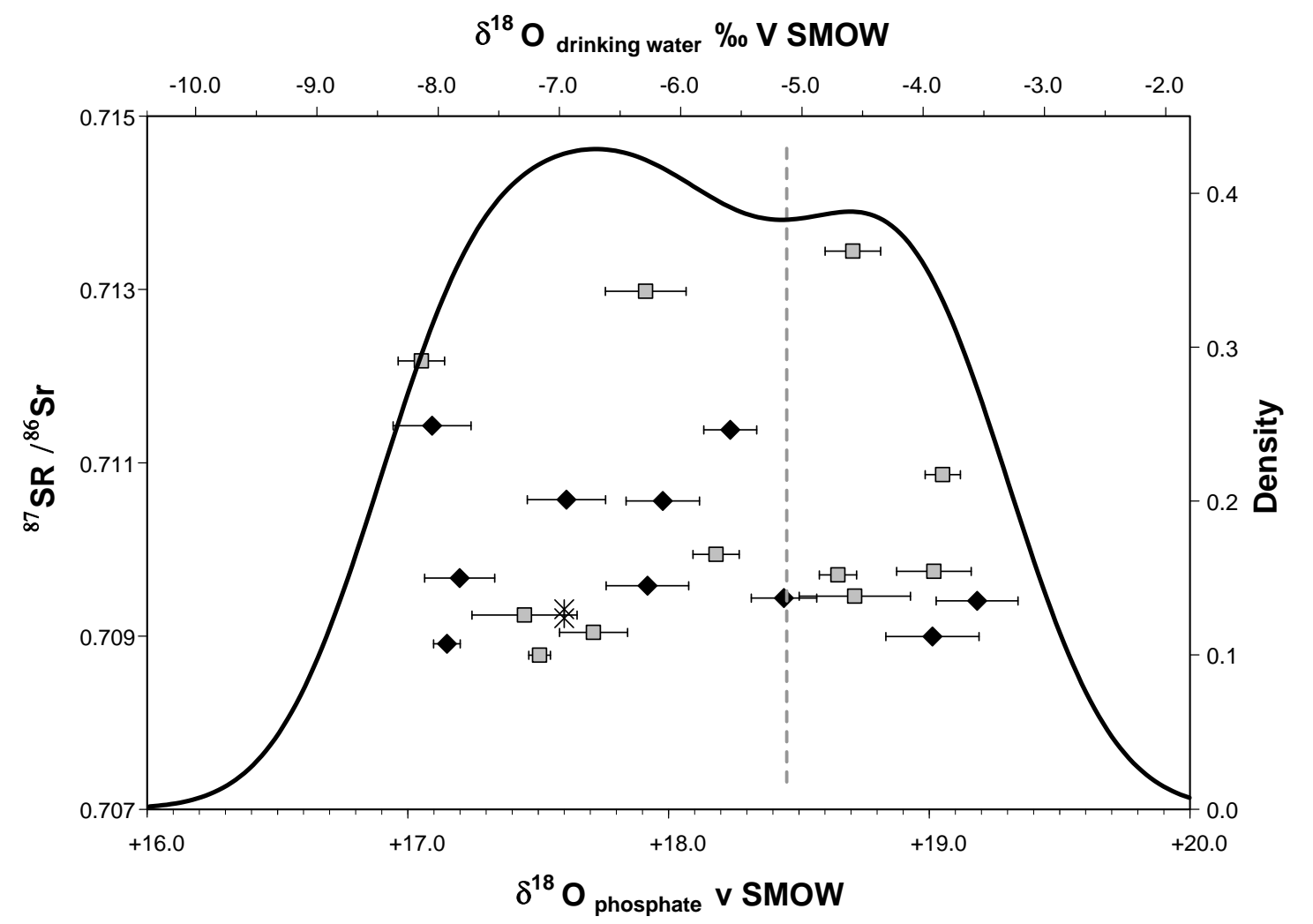

Figure 4 


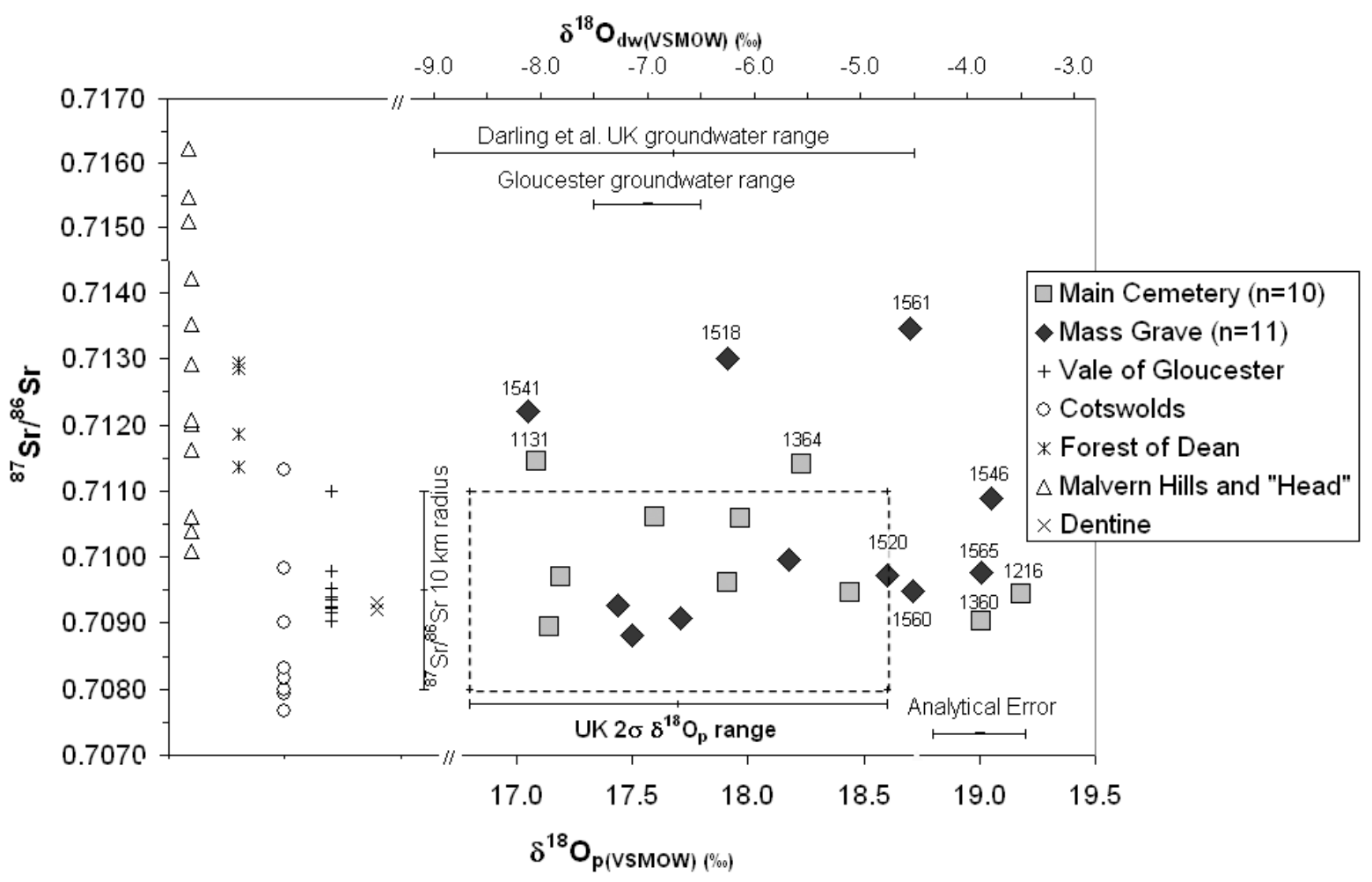

Figure 5

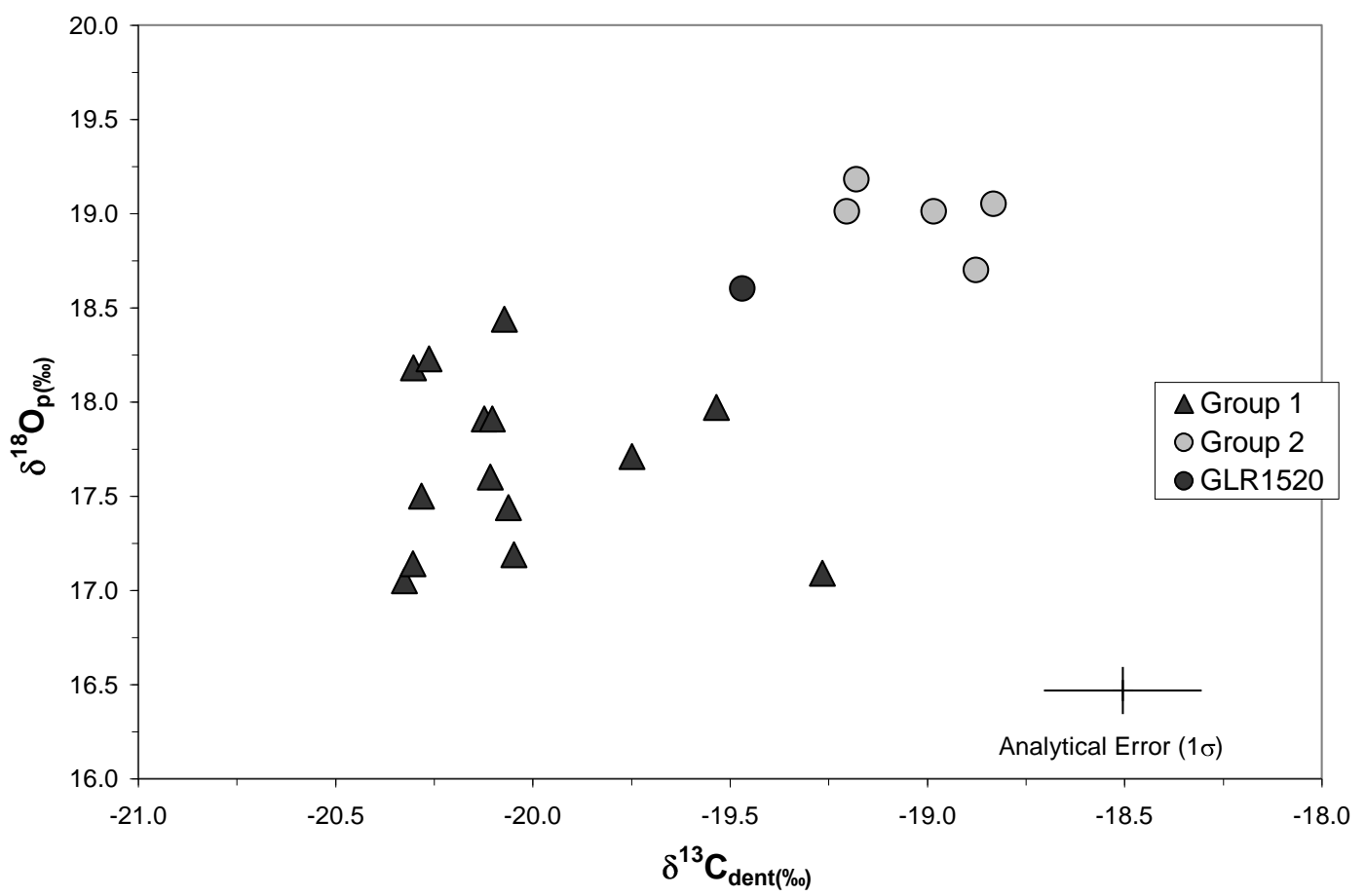

Figure 6 


\section{Technical Appendix \\ $\delta 18 O$ Drinking Water Calculations}

The isotope composition of water varies across the world in relation to climate, latitude and distance from the coast (see Darling et al., 2006). Since the oxygen stable isotope composition of skeletal phosphate is controlled by that of drinking water, measurements of $\delta{ }_{18} \mathrm{O}_{\mathrm{p}}$ in tooth enamel provide a record of the climate in which an individual was raised, thus offering a method for isotope "fingerprinting" of people. However, since oxygen is fractionated within the body, a conversion has to be applied to translate the measured $\delta 18 \mathrm{O}$ pratios in tooth enamel into the corresponding drinking water values $(\delta 18 \mathrm{Odw})$.

Phosphate oxygen/drinking water equations have been produced by Levinson et al. (1987), Luz et al. (1984), Longinelli (1984) and more recently by Daux et al. (2008), (Table A1). These equations are based on different sample sets, different estimates of comparative drinking water $\delta{ }_{18} \mathrm{O}$, different analytical methods and standards, and each give different calculated drinking water values. As a result, there remains some controversy as to which equation is most appropriate. For several years now, NIGL have been using the equation by Levinson et al. (1987), corrected for a method bias accounting for differences in analytical methodology between laboratories, as we have found that $\delta{ }_{18} \mathrm{O} d w$ ratios calculated this way provide the best fit for "expected" values derived from analyses of UK drinking water (see Budd et al. 2004; Evans et al. 2006a,b). It is the aim of this appendix to explain our

methodology and rationale for this approach.

When deriving their phosphate/drinking water equations, Longinelli (1984), Luz et al. (1984) and Levinson et al. (1987) converted bio-phosphate to $\mathrm{BiPO}_{4}$ and extracted oxygen by conventional fluorination using BrF5 (for methods see Longinelli, 1965, 1984; Kolodny, 1983). The recent work by Daux et al. (2008) analysed phosphate as $\mathrm{Ag}_{3} \mathrm{PO}_{4}$ using the sealed tube graphite reduction method (Lécuyer et al.,1993, 1996; O’Neil,1994). NIGL also analyses $\mathrm{Ag}_{3} \mathrm{PO}_{4}$ but uses the method described by Vennemann et al. (2002), involving hightemperature carbon reduction and continuous flow isotope ratio mass spectrometry. O’Neil (1994) observed that oxygen isotope analysis of phosphate converted to $\mathrm{Ag}_{3} \mathrm{PO}_{4}$ gave higher $\delta_{18} \mathrm{O}$ values than those converted to $\mathrm{BiPO}_{4}$ and stressed the need for a common standardization across laboratories. Fox and Fisher (2001) also reported difficulties in comparing data produced from $\mathrm{BiPO}_{4}$ and $\mathrm{Ag}_{3} \mathrm{PO}_{4}$ and derived their own equation to rectify the problem. Venneman et al. (2002) analysed NBS120C and a number of other phosphates by a variety of methods, and noted that analytical results varied not only for samples analysed by different methods in the same laboratory but also for samples analysed by the same methods in different laboratories. Consequently, it is necessary to correct for laboratory and method bias before any of the available phosphate/drinking water equations can be applied to data produced in other labs.

Both Luz et al. (1984) and Levinson et al. (1987) employed the analytical method of Kolodny et al. (1983), with most of the analysis carried out in the Hebrew University, Jerusalem. Neither the Luz nor Levinson papers name or provide values for reference materials/controls, however other papers from the Jerusalem laboratory, published around that time and using the same procedures, provide $\delta 18 \mathrm{O}$ values for NBS120B (Florida phosphate rock) of $+20.1 \pm 0.3 \%$ and $+19.91 \pm 0.39 \%$ (Shemesh et al., 1988 and Bryant et al., 1994, respectively). The average of these data is $20.0 \pm 0.3(2 \sigma)$. 
NBS120 is not certified for oxygen isotope values, however many laboratories use it as an in-house reference, as its matrix is more closely matched to bio-phosphate than other commercially available reference materials. Stocks of NBS120B are no longer commercially available and many laboratories now use NBS120C. As a result, few laboratories have published data for both NBS120B and NBS120C analysed by the same method. We compared values for (B) and (C) from the literature with measurements at NIGL (Table A1). The results confirm O'Neil et al.'s (1994) finding that the $\delta 18 \mathrm{O}$ value of $\mathrm{C}$ is higher than $\mathrm{B}$, but also that the difference between the two materials varies significantly with the analytical methodology.

Using the $\mathrm{Ag}_{3} \mathrm{PO}_{4}-\mathrm{TC} / \mathrm{EA}$ method routinely employed by NIGL to analyse NBS120B, we obtained $+21.4 \% \pm 0.1(\mathrm{n}=13)$ (Table A2). Before using the Luz et al. (1984) or Levinson et al. (1987) calibration equations with NIGL data, we therefore apply a method bias correction of -1.4 to the measured $\delta^{18} \mathrm{O}_{\mathrm{p}}$ value, which is derived from the difference between the mean $\delta{ }_{18} \mathrm{O}$ value for NBS120B analysed in the Jerusalem laboratory ( $+20.0 \%$, see above) and our own result of +21.4\%o. Longinelli (1984) used a similar method to Luz et al. (1984) and Levinson et al. (1987). It is therefore likely that a similar correction should be applied when using his conversion equation; however, we cannot estimate the size of the offset as there are no directly comparable data for the reference materials he used from our own laboratory. Daux et al.'s (2008) equation 4 does not require an offset correction as they report values for NBS120C which are within experimental error of our own.

NBS120C has routinely been used at NIGL as an in-house reference to normalize phosphate $\delta 18 \mathrm{O}$ during oxygen stable isotope analysis. Our own $\delta 18 \mathrm{O}$ calibration for NBS120C (as $\mathrm{Ag}_{3} \mathrm{PO}_{4}$ ) against $\mathrm{NBS} 28$ (quartz) by conventional fluorination using $\mathrm{ClF}_{3}$ as well as against NBS127 (barium sulphate) by TC/EA gave $\delta 18 \mathrm{O}$ values of $+21.70 \pm 0.15(2 \sigma, \mathrm{n}=2)$ and $+21.68 \pm$ $0.38 \%$ o $(2 \sigma, n=5)$ respectively. From these we derived our internal value for NBS120C of +21.7 . This value is in agreement with the average of published values for NBS120C, which is +21.7 $\pm 0.5 \%$ VSMOW ( $1 \sigma ; n=20)$ (see Table A3 for references).

We are fortunate in the UK to have a well-documented drinking water isotope map (Darling, 2003) and have therefore, been able to monitor and compare the results we obtain from UK populations with the known drinking water values in that area. Using this approach, we calculated $\delta_{18} \mathrm{O}_{\mathrm{dw}}$ values for humans from UK data sets using each of the available phosphate/drinking water equations, and the method bias offsets as described above, and compared them with expected local drinking water values derived from Darling et al. (2003) (Table A4, Figure A1). The $\delta{ }_{18} \mathrm{O}_{\mathrm{p}}$ values come from nine archaeological sites across the UK, ranging in age from Neolithic to Mediaeval (Table A4). From each data-set, we used only those humans which were defined as 'local' by their strontium isotope signature, resulting in 56 individuals in total. From the results, we conclude that the $\delta{ }_{18} \mathrm{O}_{\mathrm{dw}}$ values calculated using the equation by Levinson et al. (1987) (with 1.4 correction) provide overall the best fit with expected local drinking water values. They are also very similar to values computed using the two equations recently published by Daux et al. (2008) (see Figure A1). We therefore choose to continue using the corrected Levinson et al. (1987) equation to aid in the interpretation of our human $\delta 18 \mathrm{O}$ data.

The $2 \sigma$ range of the data in Table A4 also provide the current best estimate for the range of oxygen isotope data in archaeological tooth enamel that can be used to define 
individuals growing up in the UK. The population mean is $17.7 \pm 0.9 \%(2 \sigma, n=9)$. Using the corrected Levinson et al. (1987) formula, this equates to $-6.7 \pm 2.0 \%$ o $(2 \sigma, n=9)$ for UK drinking water, which, with a $2 \sigma$ range of $-8.7 \%$ to -4.75 , is a good fit with the range of modern UK fresh waters reported by Darling et al. (2003), -9.0\%o to $-4.5 \%$.

\section{Tables \& Figures}

Technical Appendix

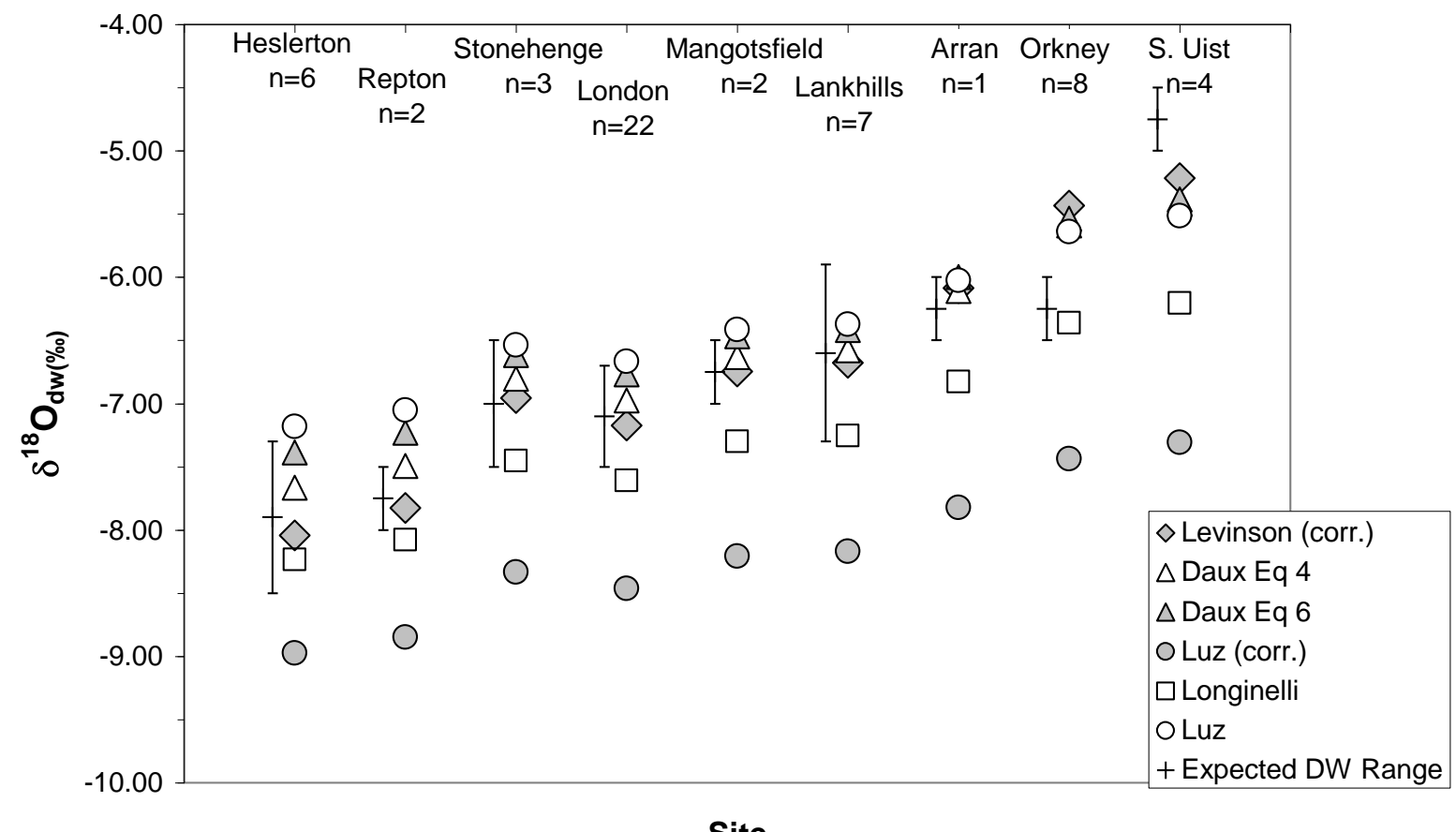

Figure A1: Mean $\delta^{18} \mathrm{O}_{\mathrm{dw}}$ ratios for "locals" from nine UK sites calculated using the available phosphate/drinking water equations in comparison with expected local drinking water values. For data and references see Table A4.

Table A1: Published $\delta^{18} \mathrm{O}$ phosphate to water conversion equations.

\begin{tabular}{|l|l|}
\hline Author & Equation \\
\hline Levinson et al., 1987 & $\delta^{18} \mathrm{O}_{\mathrm{w}}=\left(\delta^{18} \mathrm{O}_{\mathrm{p}}-19.4\right) / 0.46$ \\
\hline Longinelli et al., 1984 & $\delta^{18} \mathrm{O}_{\mathrm{w}}=\left(\delta^{18} \mathrm{O}_{\mathrm{p}}-22.37\right) / 0.64$ \\
\hline Luz et al., 1984 & $\delta^{18} \mathrm{O}_{\mathrm{w}}=\left(\delta^{18} \mathrm{O}_{\mathrm{p}}-22.7\right) / 0.78$ \\
\hline Daux et al., 2008 (eq. 4) & $\delta^{18} \mathrm{O}_{\mathrm{w}}=1.73 \delta^{18} \mathrm{Op}-37.25$ \\
\hline Daux et al., 2008 (eq. 6) & $\delta^{18} \mathrm{O}_{\mathrm{w}}=1.54 \delta^{18} \mathrm{Op}-33.72$ \\
\hline
\end{tabular}


Table A2: Comparison of published and NIGL values for NBS120B and NBS120C using different analytical methods.

\begin{tabular}{|c|c|c|c|c|c|}
\hline Author & $\begin{array}{l}\text { Pho } \\
\text { Prep } \\
\text { B }\end{array}$ & $\begin{array}{l}\text { hate } \\
\text { ation } \\
\text { C }\end{array}$ & $\begin{array}{l}\text { Oxygen } \\
\text { extraction }\end{array}$ & $\begin{array}{l}\delta^{18} \mathrm{O} \\
\text { NBS120B } \\
(\% \text { VSMOW) }\end{array}$ & $\begin{array}{l}\delta^{18} O \\
\text { NBS120C } \\
\text { (\%o VSMOW) }\end{array}$ \\
\hline Stephan, 2000 & $\mathrm{Ag}_{3} \mathrm{PO}_{4}$ & $\mathrm{Ag}_{3} \mathrm{PO}_{4}$ & ST/GC & $\begin{array}{l}+19.97 \pm 0.34 \\
\mathrm{n}=4\end{array}$ & $\begin{array}{l}+21.74 \pm 0.37 \\
\mathrm{n}=4\end{array}$ \\
\hline Wright and Hoering, 1989 & $\mathrm{Ag}_{3} \mathrm{PO}_{4}$ & $\mathrm{Ag}_{3} \mathrm{PO}_{4}$ & $\mathrm{CF}-\mathrm{BrF} 5$ & $\begin{array}{l}+19.81 \pm 0.80 \\
\mathrm{n}=12\end{array}$ & $\begin{array}{l}+19.94 \pm 0.60 \\
\mathrm{n}=7\end{array}$ \\
\hline NIGL & none & none & LAF-ClF3 & $\begin{array}{l}+20.97 \pm 0.22 \\
\mathrm{n}=12\end{array}$ & $\begin{array}{l}+21.56 \pm 0.29 \\
\mathrm{n}=8\end{array}$ \\
\hline NIGL & $\mathrm{Ag}_{3} \mathrm{PO}_{4}$ & $\mathrm{Ag}_{3} \mathrm{PO}_{4}$ & TC/EA & $\begin{array}{l}+21.39 \pm 0.09 \\
n=13\end{array}$ & $\begin{array}{l}+21.75 \pm 0.17 \\
\mathrm{n}=6\end{array}$ \\
\hline Bryant et al., 1994, 1996 & $\mathrm{BiPO}_{4}$ & $\mathrm{Ag}_{3} \mathrm{PO}_{4}$ & CF-BrF5 & $\begin{array}{l}+19.91 \pm 0.39 \\
\mathrm{n}=2\end{array}$ & $\begin{array}{l}+21.36 \pm 0.18 \\
n=13\end{array}$ \\
\hline
\end{tabular}

$\mathrm{CF}=$ conventional fluorination, $\mathrm{ST} / \mathrm{GC}=$ sealed tube graphite combustion, $\mathrm{LAF}=$ Laser assisted fluorination, $\mathrm{TC} / \mathrm{EA}=$ high-temperature carbon reduction and continuous flow mass spectrometry. With the exception of values from Bryant et al., each entry represents the same method of analysis carried out in the same laboratory. The NIGL TC/EA results were analysed in the same run and corrected against the internal value of NBS120C of $+21.7 \%$.

Table A3: $\delta^{18} \mathrm{O}$ values for $21 \mathrm{NBS} 120 \mathrm{C}\left(\mathrm{Ag}_{3} \mathrm{PO}_{4}\right)$ analysis from 19 publications.

\begin{tabular}{|l|c|c|c|c|}
\hline Author & Method & $\begin{array}{c}\mathbf{\delta 1 8 O \% o} \\
\text { VSMOW }\end{array}$ & $\mathbf{( 1 \sigma )}$ & $\mathbf{n}$ \\
\hline Bryant et al., 1996 & CF-BrF5 & 21.4 & 0.2 & 13 \\
\hline Crowson et al., 1991 & CF-BrF5 & 21.3 & 0.1 & 15 \\
\hline Daux et al., 2008 & ST/GC & 21.7 & 0.1 & 21 \\
\hline Daux et al., 2005 & ST/GC & 21.8 & 0.2 & 17 \\
\hline Dufour et al., 2007 & TC/EA & 22.2 & 0.2 & 15 \\
\hline Evans et al., 2006b & CF-ClF3 & 21.7 & 0.2 & 2 \\
\hline Fox and Fisher, 2001 & ST/GC & 21.9 & 0.4 & 6 \\
\hline Fricke et al., 1995 & CF-BrF5 & 21.8 & 0.2 & \\
\hline Fricke et al., 1998 & ST/GC & 21.8 & 0.3 & \\
\hline Lécuyer et al., 2003 & CF-BrF5 & 21.7 & 0.2 & \\
\hline Lécuyer et al., 2007 & ST/GC & 21.7 & 0.1 & 21 \\
\hline Lecuyer et al., 1993 & CF-BrF5 & 21.7 & 0.2 & \\
\hline O'Neil et al., 1994 & CF-BrF5 & 21.8 & 0.2 & \\
\hline Sharma et al., 2004 & TC/EA & 22.3 & 0.2 & 3 \\
\hline Stephan, 2000 & ST/GC & 21.7 & 0.4 & 4 \\
\hline Tütken et al., 2006 & TC/EA & 21.6 & 0.4 & 25 \\
\hline Vennemann et al., 2002 & ST/GC & 21.3 & 0.0 & 2 \\
\hline Vennemann et al., 2002 & TC/EA & 22.1 & 0.5 & 18 \\
\hline Vennemann et al., 2002 & CF-BrF5 & 22.6 & 0.1 & 3 \\
\hline Wright and Hoering, 1989 & CF-BrF5 & 19.9 & 0.6 & 7 \\
\hline Zazzo et al., 2004 & ST/GC & 21.7 & 0.2 & \\
\hline Mean $\pm \mathbf{1 \sigma}$ & & $\mathbf{2 1 . 7}$ & $\mathbf{0 . 5}$ & \\
\hline
\end{tabular}

$\mathrm{CF}=$ conventional fluorination, $\mathrm{ST} / \mathrm{GC}=$ sealed tube graphite combustion, $\mathrm{LAF}=$ Laser assisted fluorination, $\mathrm{TC} / \mathrm{EA}=\mathrm{TC} / \mathrm{EA}$ continuous flow mass spectrometry. Mean $\delta^{18} \mathrm{O}=+21.7 \pm 0.5 \% \mathrm{VSMOW}$ 
Table A4: Mean $\delta^{18} \mathrm{O}$ of phosphate for individuals with "local" ${ }^{87} \mathrm{Sr} /{ }^{86} \mathrm{Sr}$ ratios and drinking water values calculated using the five published equations $\pm 2 \sigma$ (where applicable with 1.4 method bias correction) compared to $\delta^{18} \mathrm{O}$ of expected drinking water values (Darling et al., 2003 and Darling pers. comm. $(*))$.

\begin{tabular}{|c|c|c|c|c|c|c|c|c|c|c|}
\hline Location & Period & $\mathrm{n}$ & $\begin{array}{c}\delta^{18} \mathrm{Op} \\
\text { measured }\end{array}$ & $\begin{array}{c}\delta^{18} \mathrm{O}_{\mathrm{dw}} \\
\mathrm{Luz} \\
\text { (corr.) }\end{array}$ & $\begin{array}{c}\delta^{18} \mathrm{O}_{\mathrm{dw}} \\
\text { Longinelli } \\
\text { (no corr.) }\end{array}$ & $\begin{array}{c}\delta^{18} \mathrm{O}_{\mathrm{dw}} \\
\mathrm{Luz} \\
\text { (no corr.) }\end{array}$ & $\begin{array}{l}\delta^{18} \mathrm{O}_{\mathrm{dw}} \\
\text { Daux } \\
\text { (eq. 6) }\end{array}$ & $\begin{array}{l}\delta^{18} \mathrm{O}_{\mathrm{dw}} \\
\text { Daux } \\
\text { (eq. 4) }\end{array}$ & $\begin{array}{l}\delta^{18} \mathrm{O}_{\mathrm{dw}} \\
\text { Levinson } \\
\text { (corr.) }\end{array}$ & $\begin{array}{c}\text { Expected } \\
\text { drinking water } \\
\text { range }\end{array}$ \\
\hline $\begin{array}{l}\text { West Heslerton } \\
\text { Yorkshire }^{1}\end{array}$ & $\begin{array}{l}\text { Neolithic to Iron } \\
\text { Age }\end{array}$ & 6 & $17.1 \pm 0.4$ & $-9.0 \pm 0.4$ & $-8.3 \pm 0.4$ & $-7.2 \pm 0.4$ & $-7.5 \pm 0.4$ & $-7.7 \pm 0.5$ & $-8.1 \pm 0.6$ & -7.3 to $-8.5^{*}$ \\
\hline Repton, Derbyshire $^{1}$ & Norse & 2 & $17.2 \pm 0.2$ & $-8.8 \pm 0.2$ & $-8.1 \pm 0.3$ & $-7.1 \pm 0.2$ & $-7.2 \pm 0.3$ & $-7.5 \pm 0.3$ & $-7.8 \pm 0.4$ & -7.5 to -8.0 \\
\hline Stonehenge, Wiltshire ${ }^{2,,}$ & Bronze Age & 3 & $17.6 \pm 0.2$ & $-8.4 \pm 0.3$ & $-7.5 \pm 0.4$ & $-6.5 \pm 0.3$ & $-6.7 \pm 0.4$ & $-6.8 \pm 0.4$ & $-7.0 \pm 0.5$ & -6.5 to -7.5 \\
\hline Chelsea, London ${ }^{3}$ & $17^{\text {th }}$ Century & 22 & $17.5 \pm 1$ & $-8.5 \pm 1.3$ & $-7.6 \pm 1.6$ & $-6.7 \pm 1.3$ & $-6.8 \pm 1.6$ & $-7.0 \pm 1.8$ & $-7.2 \pm 2.3$ & -6.7 to -7.5 \\
\hline $\begin{array}{l}\text { Mangotsfield } \\
\text { Gloucestershire }\end{array}$ & Romano-British & 2 & $17.7 \pm 0.2$ & $-8.2 \pm 0.2$ & $-7.3 \pm 0.3$ & $-6.4 \pm 0.2$ & $-6.5 \pm 0.2$ & $-6.6 \pm 0.3$ & $-6.7 \pm 0.4$ & -6.5 to -7.0 \\
\hline $\begin{array}{l}\text { Winchester, } \\
\text { Hampshire }^{4}\end{array}$ & Romano-British & 7 & $17.7 \pm 1$ & $-8.2 \pm 1.2$ & $-7.3 \pm 1.5$ & $-6.4 \pm 1.2$ & $-6.4 \pm 1.5$ & $-6.6 \pm 1.7$ & $-6.7 \pm 2.1$ & -5.9 to $-7.3^{*}$ \\
\hline Arran, Scotland ${ }^{5}$ & Medieval & 1 & $18.0 \pm 0.2$ & $-7.8 \pm 0.3$ & $-6.8 \pm 0.4$ & $-6.0 \pm 0.3$ & $-5.9 \pm 0.4$ & $-6.0 \pm 0.4$ & $-6.0 \pm 0.5$ & -6.0 to -6.5 \\
\hline $\begin{array}{l}\text { St Thomas Kirk } \\
\text { Orkney }^{6}\end{array}$ & Medieval & 8 & $18.3 \pm 0.8$ & $-7.3 \pm 1.0$ & $-6.4 \pm 1.3$ & $-5.6 \pm 1.0$ & $-5.5 \pm 1.2$ & $-5.5 \pm 1.4$ & $-5.3 \pm 1.8$ & -6.0 to -6.5 \\
\hline Cladh Hallan S. Uist ${ }^{5}$ & Bronze Age & 6 & $18.4 \pm 0.6$ & $-7.3 \pm 0.8$ & $-6.2 \pm 0.9$ & $-5.4 \pm 0.8$ & $-5.4 \pm 0.9$ & $-5.4 \pm 1$ & $-5.2 \pm 1.3$ & -4.5 to -5.0 \\
\hline Site Mean $(n=9) \pm 2 \sigma$ & & 57 & $17.7 \pm 0.9$ & & & & & & $-6.7 \pm 2.0$ & \\
\hline
\end{tabular}

All data are expressed in \%o (VSMOW) $\pm 2 \sigma$. Columns of drinking water values are arranged in order of agreement with expected values, poorest to best. All the above data was produced at NIGL. An analytical bias correction of -1.4 was applied to $\delta^{18}$ Op values before using the Luz and Levinson equations; for the Longinelli equation, the size of the appropriate offset to NIGL data cannot currently be estimated and $\delta^{18} \mathrm{O}_{\mathrm{dw}}$ were calculated using the original formula; no bias corrections were needed for the Daux equations (see text). Data references: ${ }^{1}$ Budd et.al 2004 (data for West Heslerton recalculated from published values that were derived using -1.0 correction); ${ }^{2}$ Evans et.al, $2006 \mathrm{~b},{ }^{3}$ Tricket, 2008 , ${ }^{4}$ Evans et.al., 2006a, ${ }^{5}$ Montgomery pers. comm. ${ }^{6}$ Toolis, submitted. 